\title{
ANALYSIS OF THE ARCHITECTURAL PLAN OF OTTOMAN MOSQUES IN ALAHSA KUT, KINGDOM OF SAUDI ARABIA IN THE 10TH CENTURY AH/16 AD MOSQUE OF ALFATIH (ALDIBS), MOSQUE OF ALQOUBA
}

\author{
ALJOHARA ALMUDARRA, ABDULLAH ALHADDAD \& ALJOHARA ALSADOUN \\ Archaeology in Major Islamic Architecture \& Art, King Saud University, Riyadh, Kingdom of Saudi Arabia
}

\begin{abstract}
Saudi Arabia is blessed with the existence of the two Holy Mosques and the spread of Mosques. Our national heritage is full of these historic Mosques, particularly Al-Hofuf City in Al-Ahsa. The searcher of the ruins of the area must be captured by the magnificence of buildings constructed by the Ottomans in the (10th AH/ 16th AD) centuries, which led us to study the Ottoman impact in the architecture of Mosques, and how architecture could overcome the difficulties and reconcile between the planning of Ottoman architecture and building materials in local environment. We had to study documents and root of this architecture, especially after the demolition of some of them, and others are on the point of destruction. The study aimed at shedding light on the most important and oldest Ottoman Mosques in Al-Kut, namely Al-Qouba and Al-Fatih Mosques, as a model for the architecture of old Mosques, as well as highlighting their functions, planning and model their architecture, characteristics, decorative architectural elements, and ways to build them to tell a story of the fragrance of the past and the depth of our traditional heritage. In this study, we applied several methods. We first used an inductive method to collect all related research materials from books to articles and oral interviews. Next, a descriptive method is utilized to further describe Al-Fatih and Al-Qouba Mosques and determine the outline of their architecture and patterns, including their roles after the field visit. Then we implement a comparative analytic method to analyse the architectural planning of the two Mosques and their structural elements, and therefore, comparing these two Mosques architecture to identify the similarities and differences between them to derive their cultural implications and local and incoming influences. We hope that our research is of scientific benefit and a crucial source of architectural knowledge for researchers.

Keywords: analysis of the architectural planning of Ottoman, Mosques in Kut Al-Ahsa, Mosques 10th century AH in Kut Al-Ahsa, Mosques 16th century AD in Kut Al-Ahsa, Al-Qouba Mosque, Al-Fatih Mosque, Al-Dibs in Kut Al-Ahsa.
\end{abstract}

\section{INTRODUCTION}

Al-Kut neighbourhood is in the northwest part of Al-Hofuf city in Al-Ahsa region, east of the Kingdom of Saudi Arabia, on a high ground, dated back to the reign of the Al-Jabriyah Empire (820-927 AH/1417-1520 AD) [1], (Figs 1 and 2).

Under the reign of Sultan Sulaiman Al Knuni, Ibn Sultan Selim (927-974 AH/1520-1566 AD), the Ottoman Empire took control of the region after the Jabriyins. The ruler directed a major military campaign of the Ottoman army, which was led by Muhammad Pasha (957$963 \mathrm{AH} / 1550-1556 \mathrm{AD})$, to dominate a number of regions in the Persian Gulf, including AlQatif and Al-Ahsa regions [2]. He makes the seat of his governance, Al-Kut district in AlAhsa, in which the Al-Fatih Mosque was built in (962 AH/1554 AD).

The Ottomans in Al-Ahsa had built numerous palaces, Mosques, schools, and markets, and they had been the first to fortify Al-Kut Fortress and built its walls and towers at the end of the tenth century $\mathrm{AH}$. 


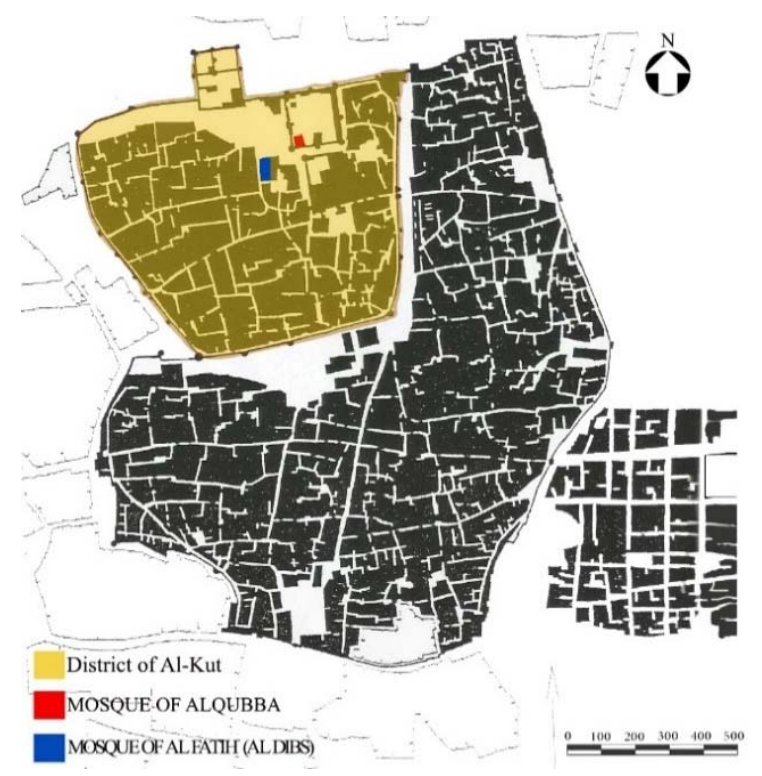

Figure 1: Map of Al-Hofuf neighbourhood, before removing the fence and opening AlKut Street (King Khalid Street). (Source: Alp, 1990.)

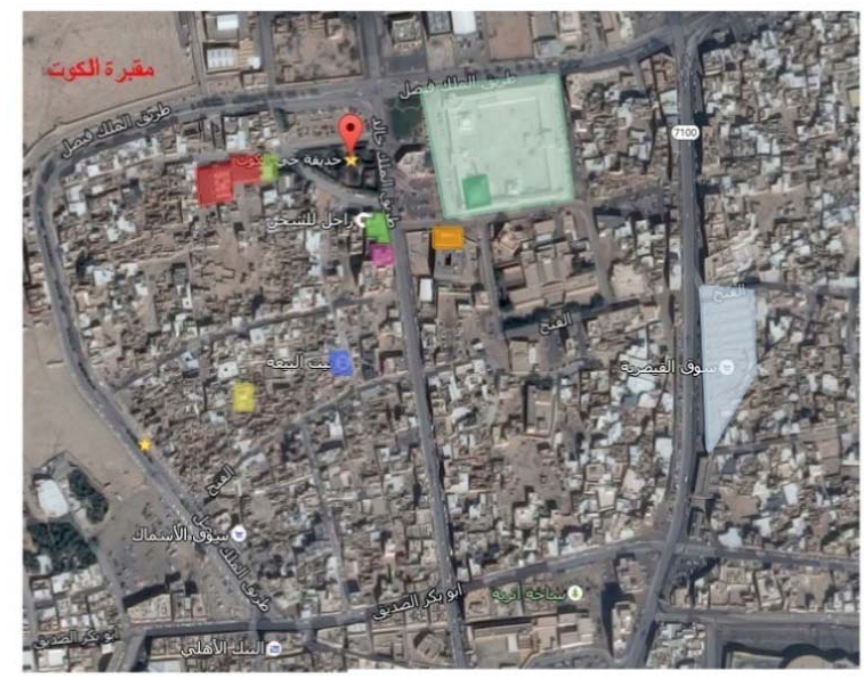

Archaeological sites close to Al Fateh Mosque and Al Qabba Mosque

\begin{tabular}{|l|l|ll} 
Cemetery of AlKut & $\begin{array}{l}\text { AL Fatih Mosque } \\
\text { (AL DIBS) } \\
\text { Ibrahim Palace }\end{array}$ & $\begin{array}{c}\text { Ribat Abi Bakr } \\
\text { Al Mulla } \\
\text { AlQubba School }\end{array}$ & AlQaesareah Market \\
\hline Jami Aljabri & Al Masfer House \\
\hline AlOthman School & AlQubba Mosque & House of allegiance (Al Mula'a) \\
\hline
\end{tabular}

Figure 2: Map of the content and the built environment of Al-Fatih Mosque and Al-Qouba Mosque in Al-Kut neighbourhood. (Source: Almudarra, 2017.) 
They proceeded to fortify the neighbourhood by digging the trenches from its four sides, including Ibrahim's archaeological palace in Al-Kut neighbourhood, in which the Mosque of Al-Qouba is located, which was founded by the governor of Al-Ahsa - Ali Ibn Ahmad Ibn Lawand (979 AH/1572 AD) [3].

Buildings in the Al-Ahsa oasis were constructed of brick and mud. Villages were surrounded by fences. Outside of the walls, there was at most places a group of huts, so villages disappear among palm trees. People are drinking water from the springs that irrigate their crops, except for Al-Hofuf City, which has its own wells [4].

We find that the Islamic countries in the Arabian Peninsula competed for Mosque architecture and to preserve their continuity and sustainability until the present time, to be a witness to Islamic architecture and our national heritage. Therefore, in our view, the Kingdom is today an open Islamic Museum. Accordingly, we should take care and show more concern to the protection and rehabilitation of the national heritage to achieve the aspirations of our good government in its vision (2030), and I draw attention to the Mosques in order to raise and activate the level of tourism and its rise to keep up with the development and a feverish race, to highlight our Islamic identity and cultural heritage.

We are all well aware that, with the passage of time and the influence of climate factors, urbanization have affected the different buildings in the neighbourhood from residential buildings and schools to especially Mosques that characterize the Islamic city, including AlFatih Mosque (Al-Dibs) and the Mosque of Al-Qouba, which has led the general authority for tourism and national heritage to rebuild some of these buildings.

The study on Mosques in this region is one of the important sources for the researchers due to its description on the architectural features of the Mosques and associated methods of construction, materials, analysis of the engineering civilization implications, and development in the Gulf region in general and the eastern region in Saudi Arabia in particular. It tells the history of the ancient countries and clarifies the cultural, social, and economic factors which have influenced its architecture.

\section{DESCRIPTIVE STUDY OF THE MASJID AND JAMI}

\subsection{Al-Fatih Mosque (Masjid)}

It was built by the Ottoman governor of Al-Ahsa, Muhammad Pasha, during the reign of Sultan Suleiman Al Kanuni in Muharram (962 AH/1554 AD) [1], [5], and the history of its architecture on a founding text can be found in the upper western wall (Fig. 3), and Al Sayed Ali Al Maghrabi and his offspring were appointed on the imamate and administration of endowments of the Mosque and the school annex [2].

Namely being the first and oldest Mosque, Al-Fatih Mosque was founded by the Ottomans in Al-Ahsa province, in Al-Kut neighbourhood, and in the centre of Al-Hofuf. Al-Fatih Mosque was built downtown of residential buildings, near to the market, and the Ottoman Empire made it the centre with Al-Kut neighbourhood buildings surrounding it when they took Al-Kut as their capital city, having the shops in the past to the north of the Mosque and of the school annex (Fig. 4).

Al-Fatih Mosque was named after the Ottoman governor Mohammed Pasha, who was nicknamed Al-Fatih, also called Masjid Al-Dibs with date markets located close to it [2].

It was built for the five imposed prayers, without Friday prayers, and most of the visitors are traders, market visitors, and students because the school teacher attached the lessons to it, so visitors could memorize the Prophet Hadith, and Koran memorization. 


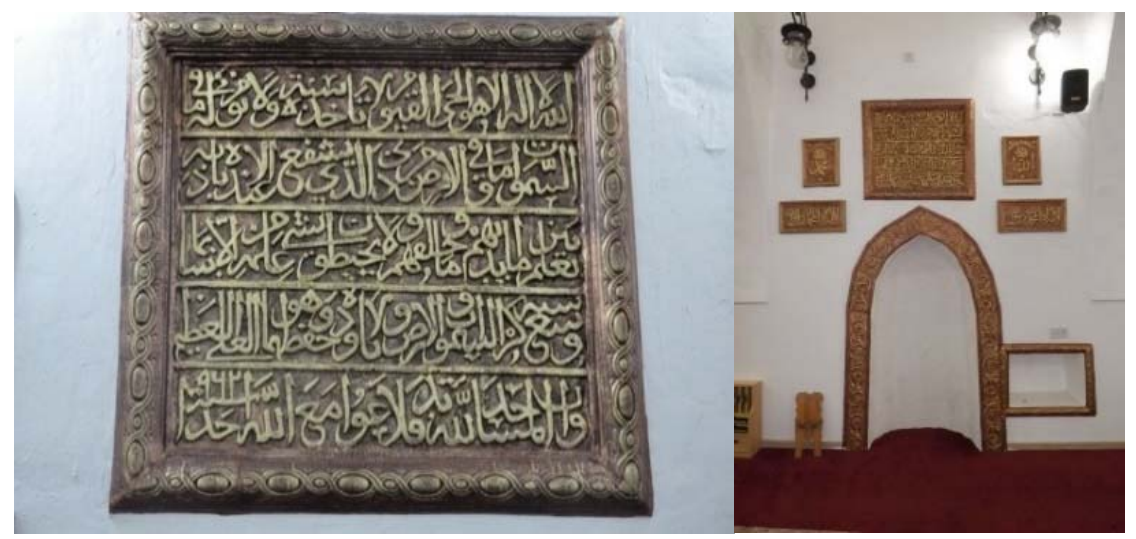

Figure 3: The fresco, showing the date of the foundation of the Mosque, appears above the last word of the text, and that is above the niche of the mihrab, and a gap to place the Koran. (Source: From the work of the researcher.)

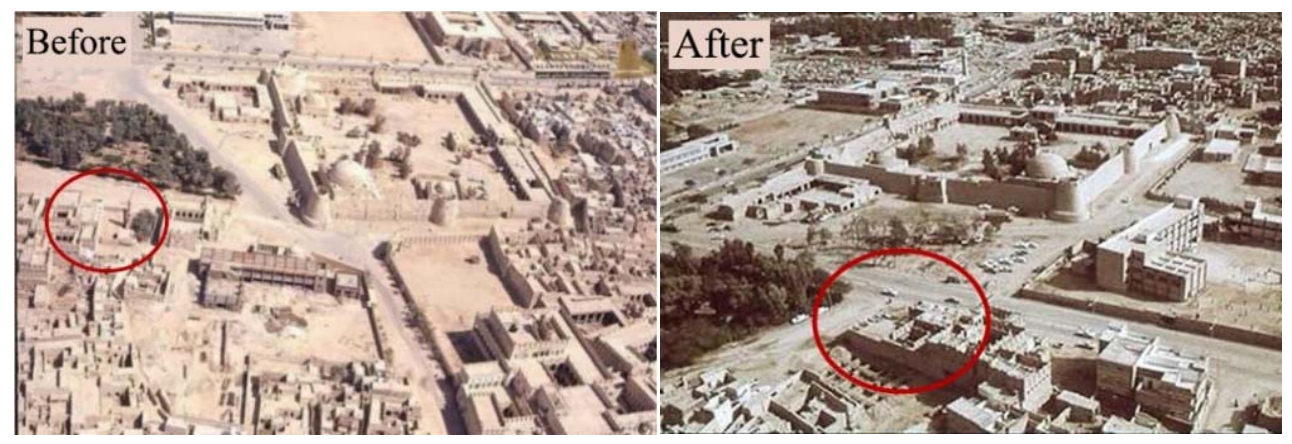

Figure 4: An old aerial photograph showing the Al-Fatih Mosque in Al-Kut District before and after the opening of Al-Kut Street in 1391 AH/1971 AD. (Source: AlRamadan, 2012.)

The walls and coverings of the Mosque were built from the construction materials available in the area, which were made up of rubble stones, unglazed limestone linking them with mud, gypsum, and small wooden sticks called Al-Bastsheel to strengthen arches. They were coated with a layer of burnt gypsum leaning to a brown colour from the outside and a white colour from the inside [6].

\subsubsection{Descriptive study of the Masjid Al-Fatih}

The Mosque was built on a semi-square land in the western part with an area of $588.57 \mathrm{~m}^{2}$, consisting of a rectangular area that is divided into a prayer hall preceded by a shaded portico with shallow domes, based on curved arches with its cylindrical pillars. The hall consists of one dome to teach the Hadith, with an area of approximately $14.99 \mathrm{~m}^{2}$, to the north of the Mosque, and the doorway in the east wall leads to the lobby of the hall, where the southern wall occupies another entrance leading to a prayer place hall. A lecture hall for memorizing the Holy Koran has two domes. The two domes are positioned to the south of the prayer place 
with an estimated total area of $23.82 \mathrm{~m}^{2}$. They are similar to the prayer place in the architectural design, alongside the entrance hall and overlooking the courtyard of a Mosque with two entrances: an inner entrance links the classroom to the lobby, and an external entrance links the lobby to the Mosque yard, which is topped with an arched with three lobes, a campus of an approximate area of $392.16 \mathrm{~m}^{2}$, and a wall of mud (Figs 5, 7 and 8), [6].

The Mosque has a minaret in the north-eastern part, consisting of a cylindrical base with a high structure, surmounted by a balcony on wooden Muqarnas, surmounted by another hull, and covered by a dome. On the top of Aljawsaq, there are four tapered arched openings (Figs 5 and 6).

There is an annex of a rectangular ablution with an approximate area of $32.64 \mathrm{~m}^{2}$ in the south-eastern part. It has a water tank and a well, containing openings for water, acting as taps called in the local dialect Palabell [7], which is used for ablution. Among them, there is a small barrier constructed of gypsum with an entrance in the north wall and a palm in the eastern part of the courtyard. The barrier has with two entrances on the fence: a doorway in the north wall leading directly up to the Mosque and doorway on the south wall on the eastern corner through the palm trees leading to the Mosque courtyard and ablution (Fig. 4 and 7).

In (1391 AH/1971 AD), the Mosque courtyard, ablution, and its old minaret had been removed. At the same time the portico was closed, leading to the Mosque by building walls, between the pillars of the gallery arches that precede the chapel, and opening in the middle arch of the entrance of the Mosque (Figs 4 and 5) [8].

It consists of a rectangular area divided into a prayer room preceded by portico entrance shaded by shallow domes.

In $1420 \mathrm{AH} / 1999 \mathrm{AD}$, after some parts of it collapsed, the Mosque was rebuilt and repaired, and the remnants of the arched portico was removed. A new minaret was built on the eastern side of the Mosque, adjacent to the inside wall. The addition to a building expands it on the west side in order to increase the number of worshippers, and a store had been added on the northern side rather than the north room (Haddith Lecture Hall) as well as a prayer place for women and a new ablution (Figs 6 and 7), with a total area of 2,389.70 $\mathrm{m}^{2}$, in order to accommodate approximately 260 worshipers. A modern decoration had been added to the mihrab, including an addition of the framing the founding inscription of the Mosque plus new written decorations on the sides [6].

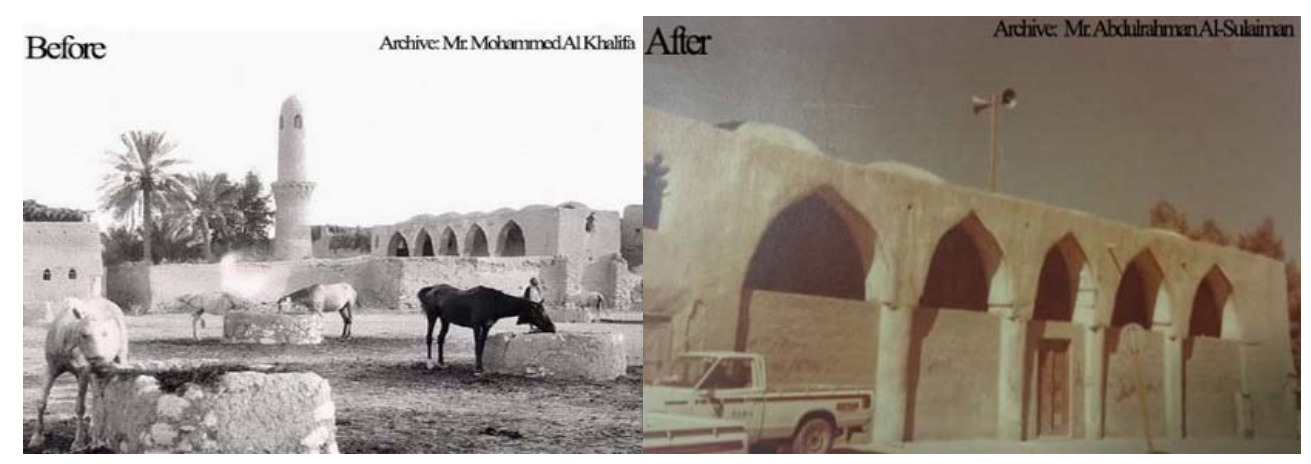

Figure 5: Al-Fatih Mosque in Al-Kut District before and after the demolition of the minaret. (Source: Kalifa and Sulaiman, 2016.) 

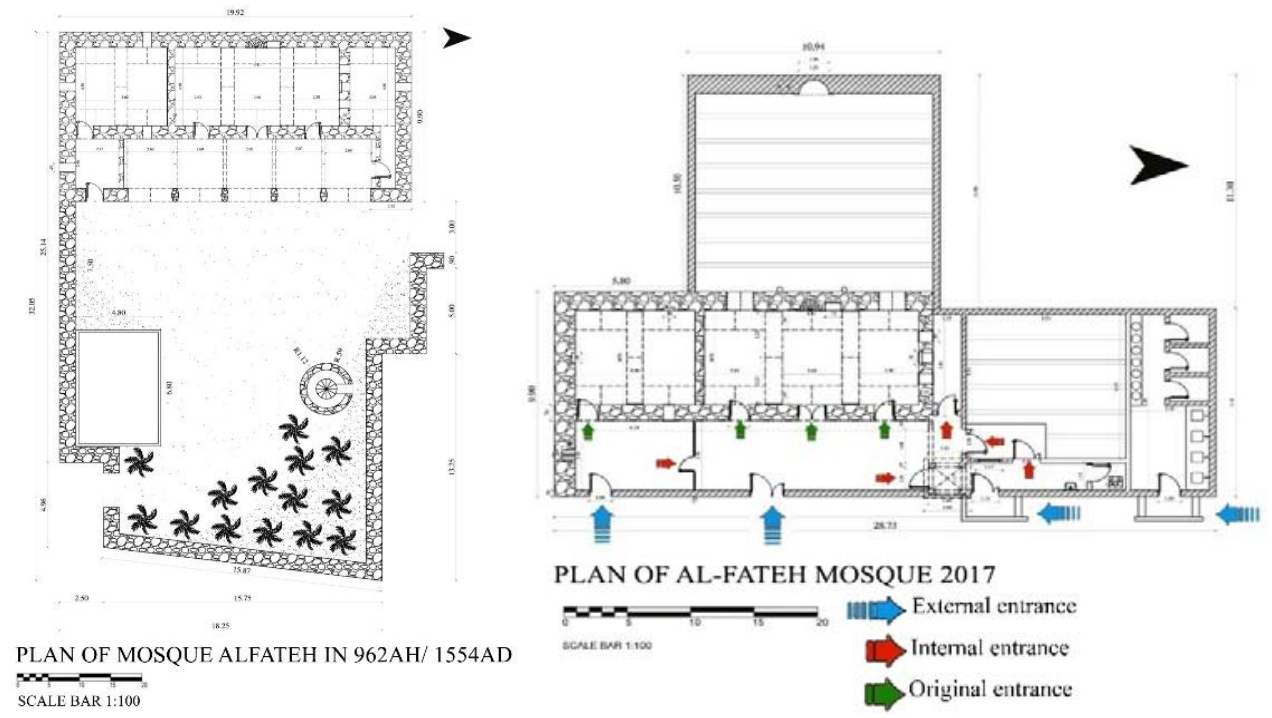

Figure 6: A ground plan depicting the original Al-Fatih Mosque when it was built in $962 \mathrm{AH} / 1555 \mathrm{AD}$ and in the last restoration phase. (Source: From the work of the researcher.)

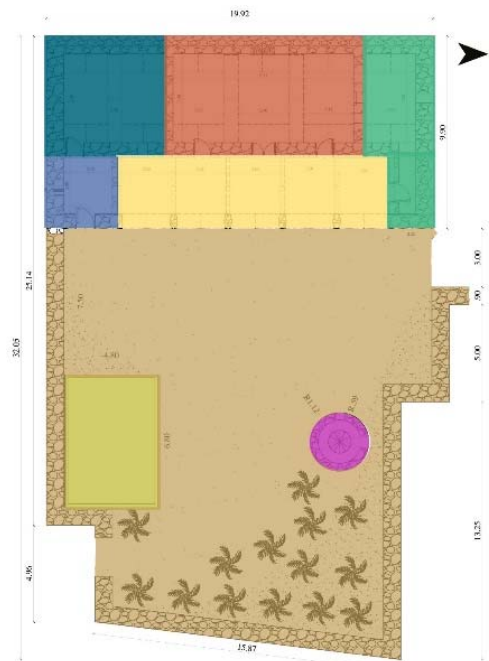

A Zone Plan for AlFatih Mousque in 965AH/ 1554AD \begin{tabular}{l|l|l|}
\hline The old Pray Hall & Al Hadith Study room \\
\hline The cntrace hall(portico) & The courtyard of the mosque \\
\hline Quran Teaching Room & A minaret \\
\hline The lobby for Teaching & Washing place for prayer \\
\hline
\end{tabular}

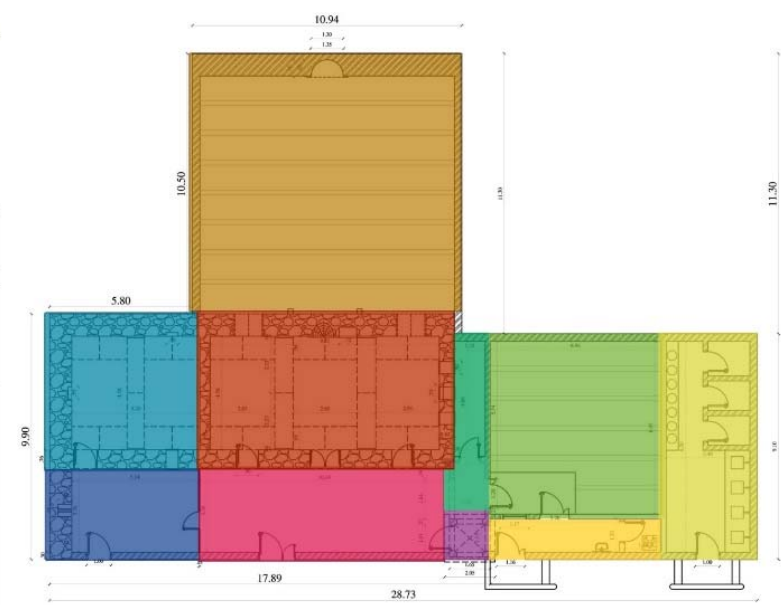

A zone plan for AlFatih Mousque For the last stage of restoration

The old Pray Hall

Quran Teaching Room

The lobby for Teaching Room

Men's prayer hall (expansion)

The yard of the mosque

A Minaret
Store
Women's prayer hall (expansion)
Women's toilet
Men's toilet

Figure 7: Zone plans showing the areas of the original Al-Fatih Mosque and and in the last restoration phase. (Source: From the work of the researcher.) 


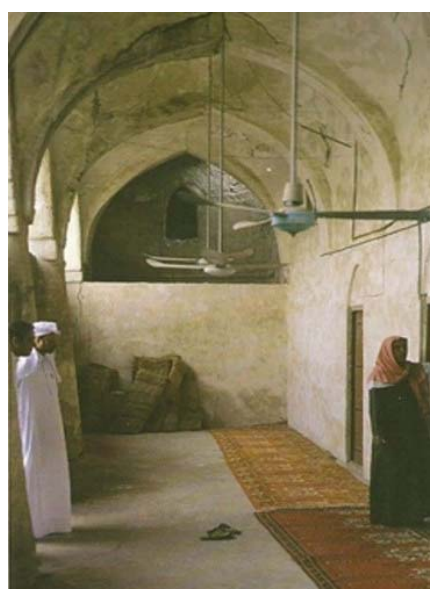

Figure 8: The entrance of the Mosque of Al-Fatih (Al-Dibs) when it was built in (962 AH/1554 AD). (Source: King, 1986.)

The present Mosque consists of two new and old sections. The old one is the subject of the study. It was planned in the form of a prayer place led by a portico, where entering is done through three entrances, passing through a portico with an estimated area of $37 \mathrm{~m}^{2}$, a length of about $13.70 \mathrm{~m}$ from the north to the south, and a width of $3.66 \mathrm{~m}$ from the east to the west side. Overlooking the Mosque courtyard, five tapered arches are parallel to the Qibla wall; other five arches are perpendicular to the Qibla wall based on cylindrical pillars, carrying shallow domes based on spherical triangles.

The inside prayer place consists of a rectangular area of $64.5 \mathrm{~m}^{2}$, extending from the north to south with a length of $10.34 \mathrm{~m}$ and a width of $6.24 \mathrm{~m}$, from the east to the west. It was divided from inside into equal three tiles from the north to the south by two vertical arches on the wall of the Qibla with a width of $4.46 \mathrm{~m}$ and a height of $4.75 \mathrm{~m}$ for each one.

Also, both of them are based on the east wall of the Mosque and the western wall (Qibla wall) (Figs 9 and 10). Each of these three tiles is covered with rectangular inflatable domes called the Bengali domes (The Bengali domes: It is Inflatable domes with an elongation resembling the shape of the cross vault, but the angles of the intersection do not appear either inside or outside. This type of domes is characterized by its elongation due to its coverage of rectangular areas).

It has a length of $2.60 \mathrm{~m}$, a width of $2.70 \mathrm{~m}$, and a height of $1.40 \mathrm{~m}$, based on the south and the north wall, on the two-pointed arches between the north and south tiles and the central tile, and six smaller the pointed arches with two arches per each tile adjoining the eastern and western walls, and it is has a width of $2.60 \mathrm{~m}$ and a height of $4.75 \mathrm{~m}$ from the ground (Figs 10 and 11$)$.

In the middle of the Qibla wall (Western Wall) of the central tile, there is the niche of the mihrab that has from the top a pointed arch, containing a six-sided entry with a half circular niche. Its circumference decreases as it rises until its top ends with the mihrab boater. The bottom and the boater of the mihrab were covered with burned gypsum from inside, with a white colour without decorations, but now, they are painted with white gypsum decorations. Next to the mihrab on the right side, there is a rectangular entry called Kuttabiya (Kuttabiya: It is called Al Farigha consisting of a large space in the walls, in the form of the opening of 
the closed window, this element may arise by joining two walls together, open in the opposite wall space in size and shape required, and Al-Farigha may be buried in the wall deeply such as the alcove and wall Al-Farigha which is thus functionally similar to the alcove. In terms of form, however, kuttabiya is not often provided with cosmetic plaster elements), for the placement of the Koran. The inside cavity was covered with white gypsum with no decoration inside it (Figs 3 and 12).

The mihrab is topped by a rectangular panel with the inscription of Al-Kursi verse (255) of Surah Al-Baqarah in addition to a verse (18) of Surah Al-Jinn, and the date of the Mosque's construction was in $962 \mathrm{AH}$ with Thuluth handwriting (Fig. 3) [6].

The eastern wall has three entries with an entry per tile leading to the outside of the Mosque. The two side entrances are crowned by a half ring; the main middle entrance is closed by a double-edged wooden door. Each door opening is topped by a tapered slotted opening. The northern wall also has three tampered arched openings all for its illumination and ventilation (Figs 9 and 10), and under the northern wall openings in the middle, there is Kuttabiya in the shape of a rectangular entrance for the preservation of the Holy Quran. On the left, there is a shelf of gypsum for lighting lamps (Figs 3 and 9).

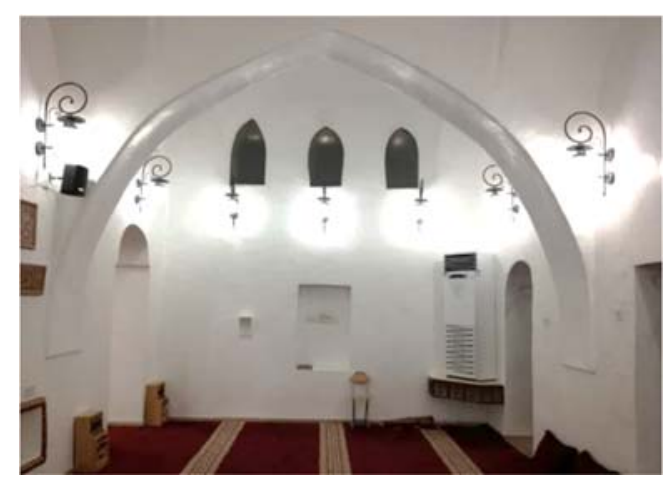

Figure 9: The northern vertical contract on the Qibla wall is based on the Qibla wall and the northern wall opposite it, which is occupied by closed windows that make up the northern wall. (Source: From the work of the researcher.)

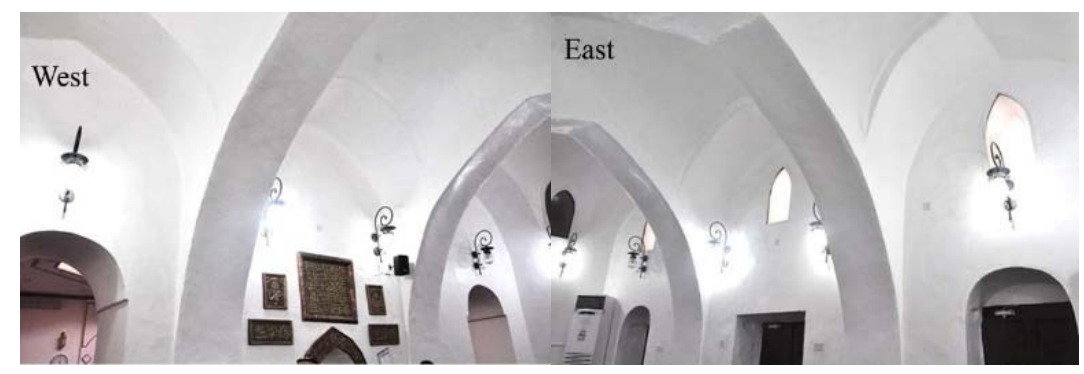

Figure 10: The northern and southern arches are perpendicular to the Qibla wall. They are based on the Qibla wall and the eastern wall opposite it. They also show the roof of the Mosque with the smaller vertical beams on it. (Source: From the work of the researcher.) 


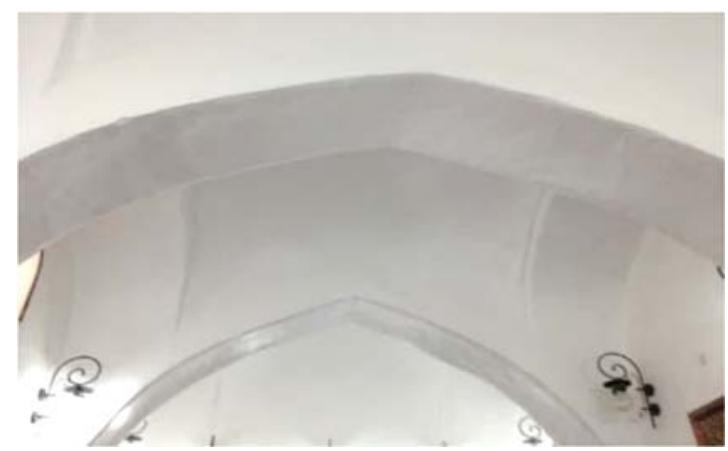

Figure 11: Shows the elongated dome, the roof of the Mosque and its base on the two vertical arches on the Qibla wall, and two the small arches parallel that of the Qibla wall. (Source: From the work of the researcher.)

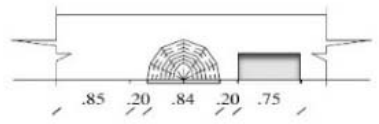

\section{PLAN}

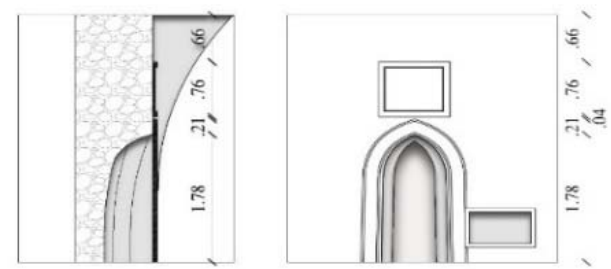

\section{SECTION}

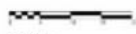

Figure 12: A horizontal plan and a detailed section of the Al-Fatih Mosque. (Source: From the work of the researcher.)

\subsection{Ali Pasha Jami in Hofuf}

The Mosque is located in the southwest corner of the palace of Ibrahim located in the north of Kut neighbourhood. A part of an architecture group, in addition to the Mosque, includes a school, an office, a solider room, a water tank, and washing places for ablutions for prayer and subsequent benefits and rights. (Figs 1, 2, 13-15) [9].

The governor of Al-Ahsa Ali Pasha ordered to establish this group during the reign of Sultan Selim II (974-982 AH/1566-1574 AD) in the year 979/1571 AD as evident by the founding inscriptions of the Mosque registered at the top of its main entrance (Figs 16 and 17) [9]. 


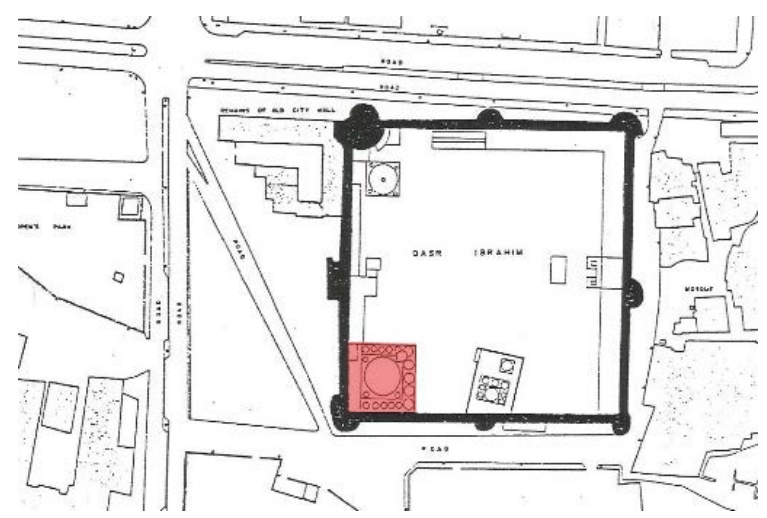

Figure 13: The location of Al-Qouba Jami inside Ibrahim's palace. (Source: Alp, 1990.)

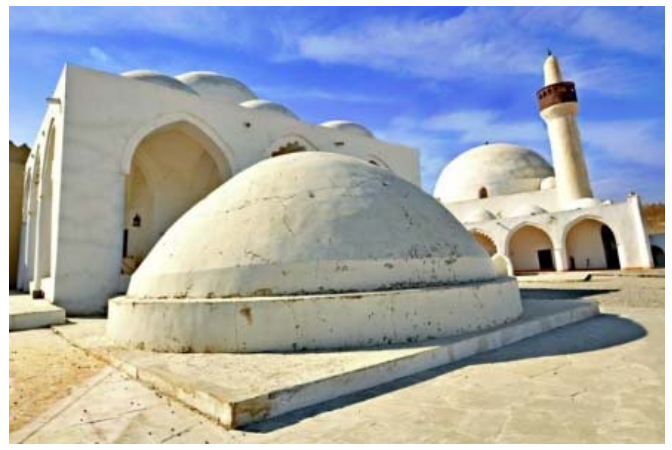

Figure 14: School near to Jami Al-Qouba. (Source: Alfhaid, 2010.)

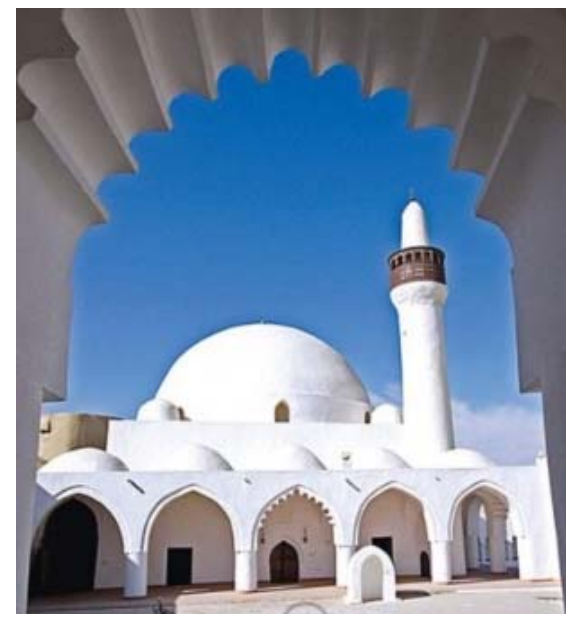

Figure 15: Jami Al-Qouba from the eastern side. It shows us the centre and small dome from outside and a minaret (Source: Alfhaid: 2010.) 

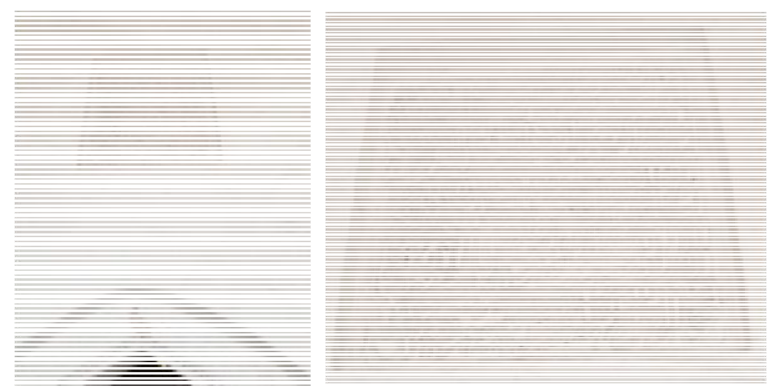

Figure 16: Inscriptions appear above the main entrance in Jami Al-Qouba in Al-Ahsa. (Source: From the work of the researcher.)

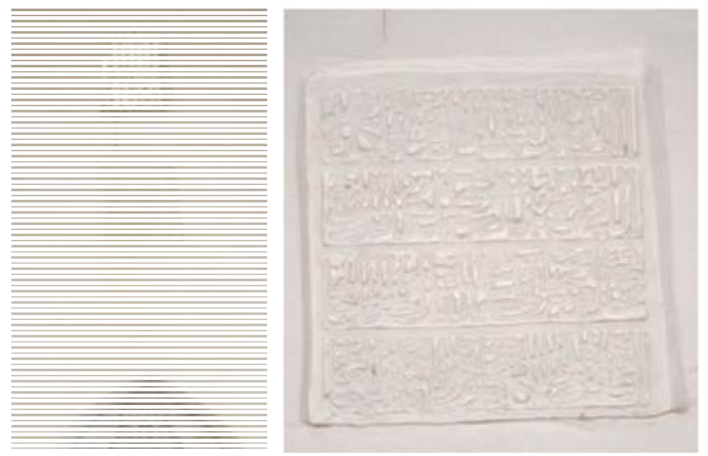

Figure 17: Inscriptions appear above the mihrab in Jami Al-Qouba in Al-Ahsa. (Source: From the work of the researcher.)

\subsubsection{A descriptive study of the Jami}

In the construction of this Jami, the stone Al-Debash and the brick Al-Aja'ar were used. The first one was used to build walls, pillars, and supports as well as the lower part of the minaret. The second one was used to build arches, roof, and the above part of the minaret. The construction materials were covered with a luting layer of mixed plaster, and wood was also used to build the sills of the windows of the dome [9].

The Mosque was designed on a square area with a side length of $15.60 \mathrm{~m}$ from the inside (Fig. 18). The mihrab comes at the centre of the western wall. It is a half circular bend, crowned with pointed arches with Muqarnast (Muqarnast: It is decorative moulding of blind arches forming stalactite-like ornament much favoured in the Islamic world) [10] from the inside. The mihrab is topped by a four-line inscription in the Thuluth script. The inscription contains verses from Surat Al-Isra'a (verses 78-82) and a three-stairs minbar (Figs 16, 17 and 19). There is an entrance in each side with a rectangular opening window with arches and spears and beads (Fig. 20). The main entrance door intercedes the eastern wall with tampered arches. This arch is topped by the founding inscription of the Mosque. It consists of five lines written in the Thuluth script containing verse 18 of Surah Al-Tawbah as well as the name of the Ottoman Sultan Salim II and his nicknames. In addition, a frame decorated with almond pattern from a plaster with the name of the builder of the Mosque, Ali Pasha and the date of construction, in the early month of Rajab in 979 AH/1571 AD (Fig. 16) [11]. 

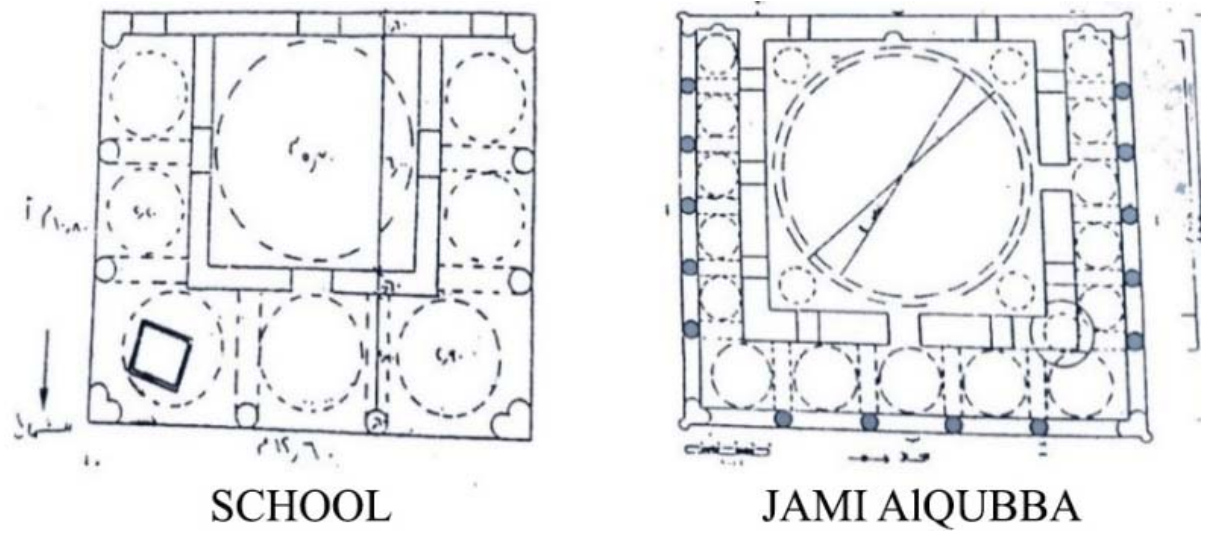

Figure 18: Plan for school Jami Al-Qouba in Al-Ahsa and Plan for Jami Al-Qouba in AlAhsa. (Source: Ghobashi, 1986.)
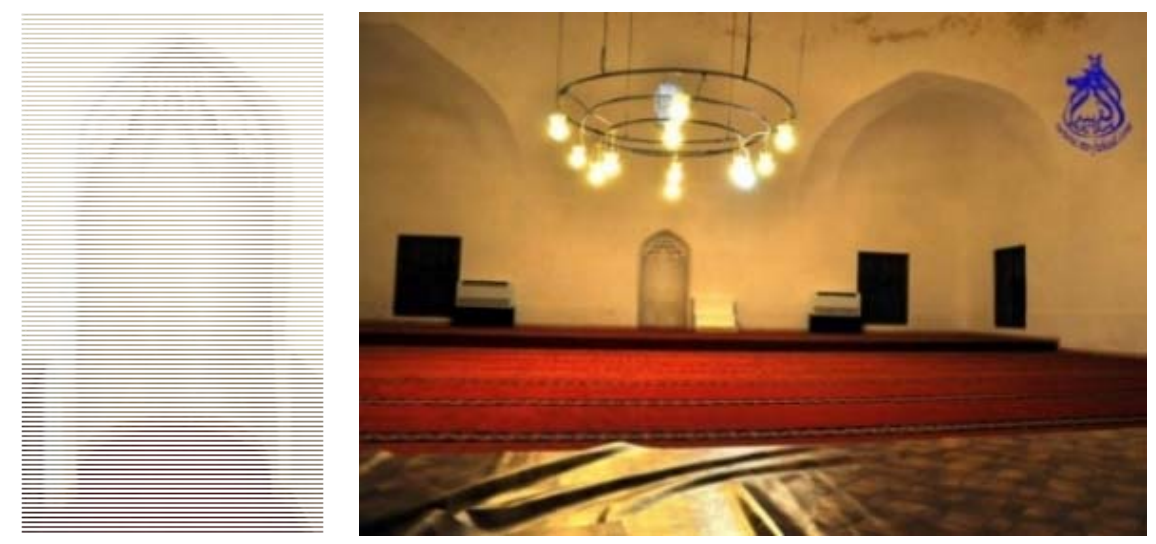

Figure 19: Mihrab and Minbar. (Source: Alfhaid, 2010.)
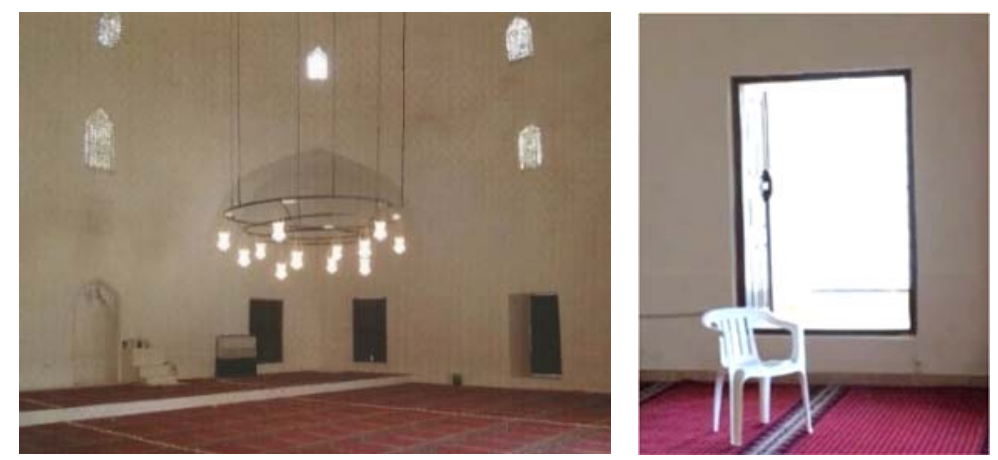

Figure 20: The high and lower window in Jami Al-Qouba. (Source: AlHussein, 2003, Source: From the work of the researcher.) 


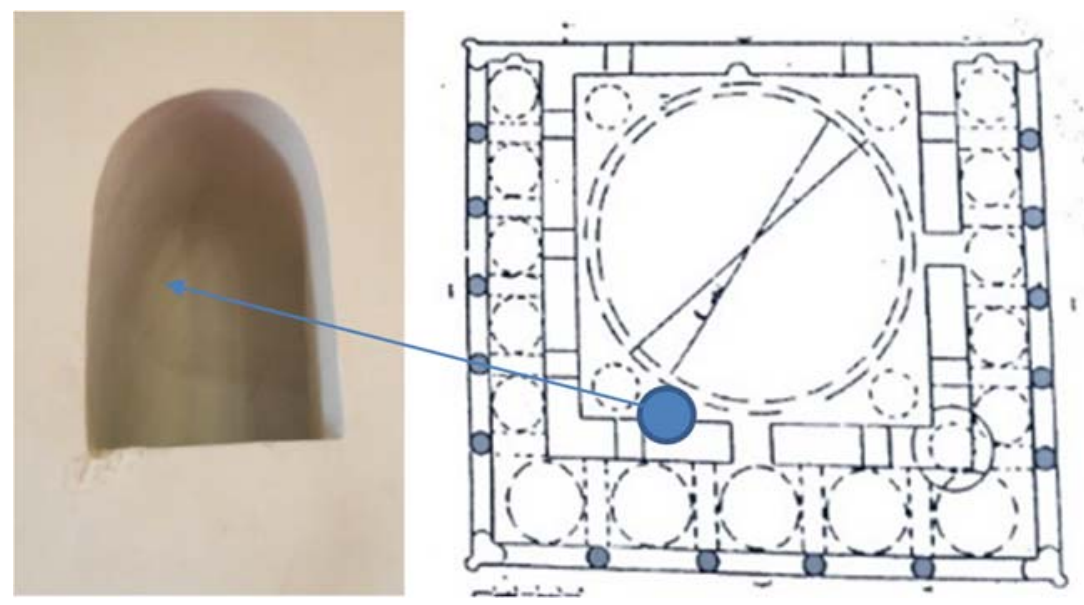

Figure 21: Place the small window for denouncer bench. (Source: From the work of the researcher.)

There is, on the right inside of the main entry door, a tampered arched opening to reach a five-step staircase, leading to the denouncer bench. This bench overlooks the inside of the Mosque through a half circular arch. On either side of the main entrance, there is an entrance to a rectangular window with staves of spears and beads (Fig. 21). An arched door opening intercedes the northern wall with two entrances on its sides, with one entrance on each side similar to previous openings, and the southern wall contains three similar entries (Fig. 20).

This Mosque is covered by a half spherical huge dome with a diameter of $13.80 \mathrm{~m}$ and a depth of $6.80 \mathrm{~m}$ (Fig. 22), based on a transition area consisting of four, large sided bends with tapered arches (Fig. 22). These bends are topped by four small domes from the outside (Fig. 15). Each dome has a door opening with tapered arches, so there are two rows of windows. The first row is at a height of $5.40 \mathrm{~m}$ from the floor of the Mosque upward, consisting of four arched windows, which are covered with plaster and engineering vegetal decorations (Figs 20, 22 and 23).

The castanets of the dome come after the neck and continue to the pole. Then the dome has its hanging strings. The lantern light at the bottom of the dome is like its surface, smooth and free of decorations (Fig. 20).

The Mosque is surrounded by a portico from the eastern side, and on the northern and southern sides, there are three porticoes surrounding the Mosque from three sides, except the direction of the Qibla, i.e. the western side (Figs 15 and 23).

In the centre of the two northern and southern porticoes is a small hollow niche side (Figs 15 and 23). These three porticoes are covered by shallow domes of mud bricks with a layer of plaster. The transition area of these domes is spherical triangles. These domes consist of fifteen domes with five domes covering each portico. The largest of which is the dome of the eastern portico, whereas the domes of each of the southern and northern porticoes are equal.

These porticoes have façades of three arcades. Its arches are based on four slipways but in the corners are different pillars, in its forelocks are tower buttresses in order to bolster the corners, and there are fourteen circular short pillars with four pillars of the façade on the eastern portico side (Figs 15 and 23); five pillars on the façade for both the northern portico and southern portico. 


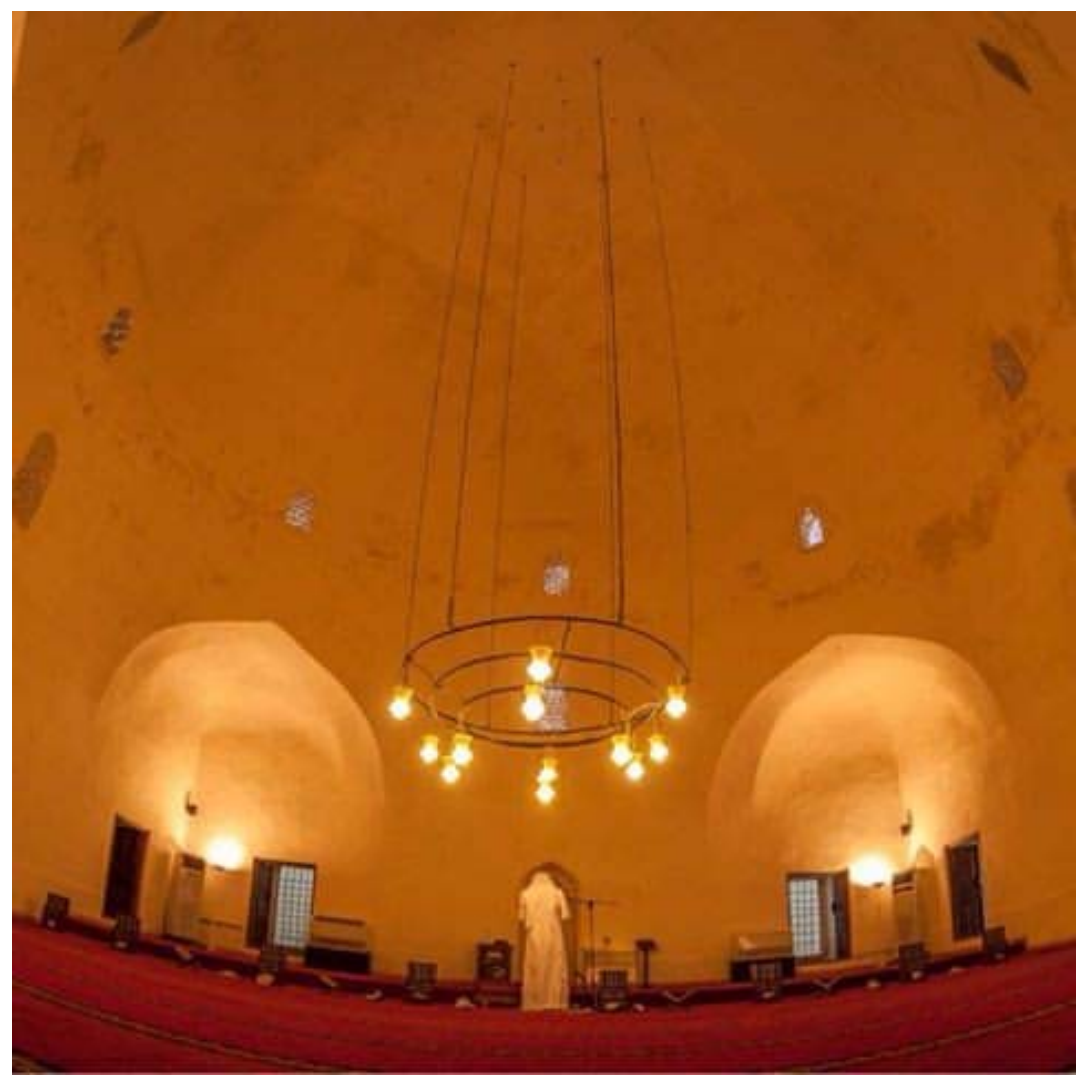

Figure 22: The dome and the Corner arches in Jami Al-Qouba. (Source: Imgrum, 2017.)

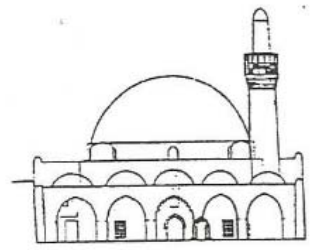

EAST

BUILDING R (MOSCUE)

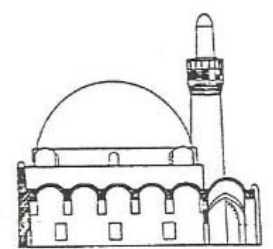

SOUTH SECTIONA-A

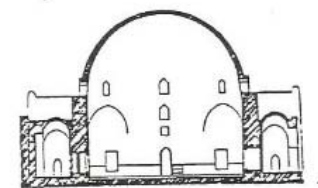

SECTION B-B

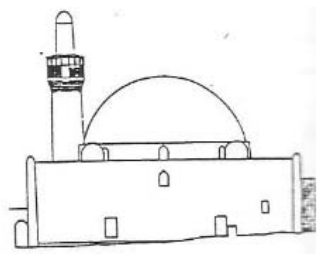

NOURTH

Figure 23: Three porticoes surrounding the Mosque from three sides except the direction of the Qibla, i.e. the western side. (Source: Alp, 1990.)

The arches of these arcades are limited to two types: a pointed arch and a lobed arch, or the multi lobed. This Mosque has a minaret in the northeast corner as well as a cylindrical tower extending upward. It is crowned with mounting muqarnas, bearing a roofed veranda that is wrapped around the second part, a short cylindrical tip leads to the conical top of the minaret, and a spherical stock centralizes on the apex, which is referred to as "the apple", and above it, the crescent moon mediates the side (Fig. 15). 


\section{ANALYTICAL AND COMPARATIVE STUDY OF AL-MASJID AND AL-JAMI}

\subsection{Location selection}

Islam is about selecting a good and appropriate location to build a Mosque. It is the core for every residential collection and an essential element in the architecture of Islamic cities. The importance of Al-Fatih Mosque location and Al-Qouba Jami is distinguished by several things. They had been built in the city of Al-Hofuf in Al-Kut neighbourhood, on a high land compared to other lands in Al-Ahsa region, away from diseases and epidemics, to facilitate its fortification walls and defensive towers (It is a rectangular stone block, is cut and formed in the quarries columns before carrying them to the construction site, preferably the type of formable solid stones. It is one of the architectural elements complementary to the function of the columns used to increase the height of columns, along with its cosmetic body) (Figs 1, 2 and 24).

Al-Fatih Mosque (Al-Dibs) was built in the middle of residential buildings and near the old Hofuf market, as evident by the existence of the shops in the northern side of the Mosque near its annex school, to teach the Holy Quran [6], to serve the market goers, students, and the Ottoman military garrison members, and to perform the five prayers. With consideration of the prior, the nearby Mosque built during the former Al-Jabriyah Sultanate, before the Ottoman Empire, functions as aljami, or as a Mosque specifically for Friday prayers (Fig. 1 and 3).

Al-Qouba Jami was built inside Ibrahim's palace in a later period [11], which shows us the importance of Al-Jami location as the state Mosque, where people gather to perform Friday prayer and Eid and members of the military garrison later, in addition to the five prayers and the study (Figs 1 and 13).

The Ottoman governors made a great effort to promote religious and cultural studies, which made Al-Ahsa a prosperous centre of religion and culture that attracted numerous scholars. They built Mosques and schools, and the spiritual and cultural factors are represented in Al-Kut neighbourhood in Al-Fatih Mosque and Al-Qouba Jami. We believe that the reason for building Al-Fatih Mosque under the Ottomans, when taking on a new area to build Mosques and defense mansions, is to control or consolidate the position of the state in the region [13].

Thus, Al-Fatih Mosque had made a social contact between the coming dominant authority and the residents nearby, as well as merchants and clients of the market, forming an important dimension in the market environment. Its minaret's height and size graduality indicates spirituality, and its body dominates the overall sense of the centre, giving people a sense of peace, familiarity, and security from the unknown.

An important feature of The Ottoman Islamic architecture is the building of Mosques in the complex or palace, consisting of several different annexes that depend on the region's need. Therefore, we find uniqueness in the construction of Mosques from other residential and commercial buildings, with the establishment of a high external wall to surround the complex or the palace and the Mosque. It also appears in the building of Al-Qouba Jami Mosque, inside Ibrahim's palace and near the school [13].

When establishing the origin of the Masjid and Al-Jami site, we find that the model followed in the footsteps of many old neighbourhoods in the Islamic cities, where the Mosque, the market, and the large arena are the heart of the urban environment, injecting life into arteries and embody the members on the streets and the space components. For instance, the site of Imam Faisal bin Turki Mosque in Al-Na'athel neighbourhood of Hofuf and to the 


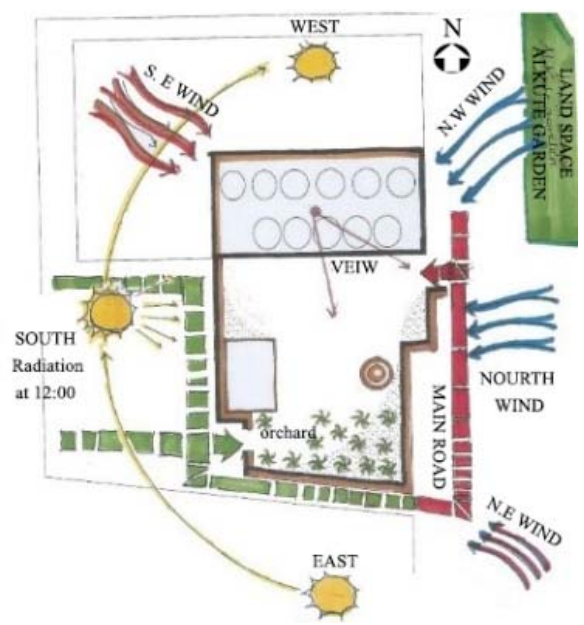

Figure 24: Explain the content and the environmental environment on the Al-Fateh Mosque building. (Source: From the work of the researcher.)

site of the Kufa and Basra Mosques were founded by the Muslims. In the era of the Caliphs in Iraq, they began planning the Mosques. The Mosques became the nucleus of the city in $1737 \mathrm{AH}[26]$. As for Al-Qouba Jami within a complex or a palace, Al-Fatih Mosque was built in the year $867 \mathrm{AH} / 1463 \mathrm{AD}$, and Al-Sulaymaniyah complex Mosque was built in 957 $\mathrm{AH} / 1550 \mathrm{AD}$.

When compared with the date and location of Al-Fatih Mosque and Al-Qouba Jami, we find each Mosque to have distinguished characteristics, with a unique identification in function and architectural design that have helped the diversity of architectural styles in the region, under the local influence of the region, gaining a distinguished type specificity.

\subsection{Planning}

Al-Ahsa, under the guardianship of the Ottoman Empire, developed two distinguished models that appeared in Ottoman Mosques:

The first stage model is the Ottoman architecture that is affected by the Seljuk architecture, which is a multiple and symmetrical dome planning, and the most important example of such phase is the Grand Mosque of Bursa built in 789 AH/1396 AD and represented by the AlFatih Mosque in Al-Ahsa [16].

The second stage model is the golden stage of Ottoman architecture, where the central dome appeared with a clear influence of the church of A'aya Sophia, in terms of the huge size and height of the dome and a lack of columns, which characterized the school of architect Sinan Pasha, giving a particular architectural identity to Ottoman architecture, i.e. a model of Al-Qouba Jami inside Ibrahim's Palace in Hofuf [13].

At the consolidation of planning for each Mosque, we find that the first pattern model had built Al-Fatih Mosque, according to the model of the five-prayer Mosques in the shape of a rectangular prayer hall, which was covered with three domes of equal size over the Mosque from the south side, and the classroom was annexed with two domes.

At the consolidation of this model of planning the Mosque, it was known in the early Islamic architecture, which probably had been influenced by the construction of scenes in the 
age of the governors, and then Fatimid funerary domes dating back to the era of the Fatimid minister of Al Afdal bin Badr Al-Jamali (487-515 AH/1094-1121 AD), including a scene in Aswan in southern Egypt (493-504 AH/1100-1110 AD), and the scene of Lady Ruqaya in Cairo [11], (527 AH/1133 AD) (Fig. 25).

The similarity is shown in the prayer hall, consisting of a rectangular area, divided into three square areas, covered by three domes in Al-Fatih Mosque, while covered in the former Fatimid Mosques with a central dome and side domes. It was also shown in the Mosque of Agnas in Taaz built in $623 \mathrm{AH} / 1226 \mathrm{AD}$, which was covered with three domes, and its pray hall is similar to Al-Fatih's prayer hall. This planning had the term "the heart and wings" [17].

The essence of planning this model consists of a rectangular area, divided by two vertical arches on the Qibla wall of three boxes, covered by three domes or a central dome and two side domes. This model of planning in the Muslim Seljuk period had spread until the early Ottoman period in Mosul City, El Mojahdi Jami (572-576 AH/1176-1180 AD), Nebi Jami (Jami Nebi) in Diyar Baker (936 AH/1529 AD), Al-Safa Jami in Diyar Baker (938 AH/1531 AD) (Fig. 25) [18], and Anbriyah Mosque in Medina (1326 AH/ 1908 AD) [11].

The Seljuks followed this planning in their chapels because it corresponds to the cold environment in which they live, and in order to block the cold air from the chapel. The design was developed by adding an entrance walkway supported by porticoes in the Mosques of the Anatolian picture and removing the fenders and the rear. This planning characterized the Ottoman architecture in its first period. Since the planning of Al-Fatih Mosque is associated with this simple model, we refer to the Mosques in Medina, which were designed according to this design, the Mosque of Al-Suqayya in Al-Medina and Al-Jumah Mosque established in 939-948 AH/1532-1542 AD by the Ottoman Sultan Suleiman Al Kanuni, and Ali Ibn Abi Talib Mosque established in 1268-1269 AH/1851-1852 AD by the Ottoman Sultan Abdul Majid I [11] (Fig. 25).

As for Al-Fatih Mosque that contains a courtyard leading up to the prayer hall and a minaret in the southeast corner, we watch this planning in the Ottoman prayer hall as the Mosque of Sultan Beyazid II in Amasia (891 AH/1486 AD) and Al-Mouradah Mosque in Manisa (993 AH/1585 AD) [18], and in Al-Qouba Mosque in Al-Ahsa (974-979 AH/15661571 AD), and the Mosque of Al-Jum'ah in Medina (939-948 AH/1532-1542 AD), and Ali bin Abi Talib Mosque in Medina [11] (Fig. 25).

When consolidating Al-Qouba Jami, we find that it was known in Islamic architecture long before the Ottoman Era, especially in the design of some of the funeral domes. The oldest remaining examples of Islamic architecture date back to the era of the governors, such as a tomb of Aswan cemetery that is in south Egypt (Fig. 26).

Such increase is not strange to early Islamic architecture since it is surrounded by Mosques, which were designed according to unconventional planning, i.e. planning with halls without an open central courtyard. Early Islamic architectural Mosques were built during the end of the Umayyad period, similar to Qasr Al-Hallabat Mosque in Jordan, whereas some other Mosques were designed according to the traditional planning, which comprises of an open middle courtyard, a rear, fender, and forepart. Examples of the traditional planning are the Mosque of Samarra (234-237 AH/848-852 AD) in Iraq during the Abbasid Era and the Mosque of Ahmad Ibn Tulun (263-265 AH/876-879 AD) in Cairo. Larry Galabi Mosque in Edirna (920 AH/1514 AD) is considered the oldest model remaining in the Ottoman architecture and the Islamic architecture in general (Fig. 26), especially this pattern is designed according to the evolving model of Al-Qouba Mosque and the plan of the Abu Dahab Mosque towards Al-Azhar in Cairo (Fig. 26). 


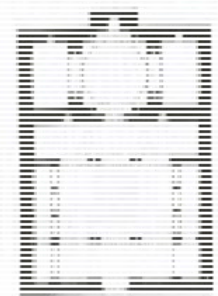

(a)

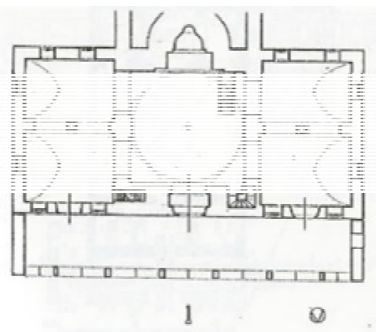

(c)

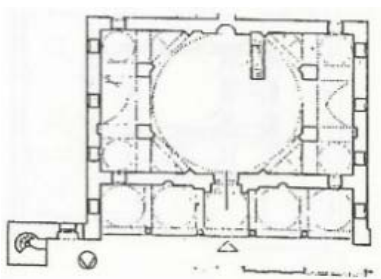

(e)

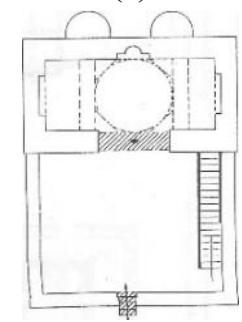

$(\mathrm{g})$

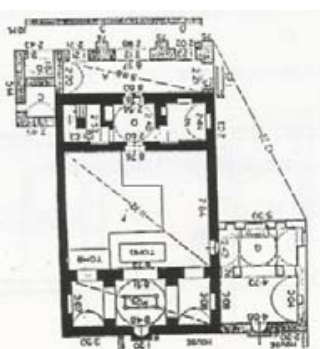

(b)

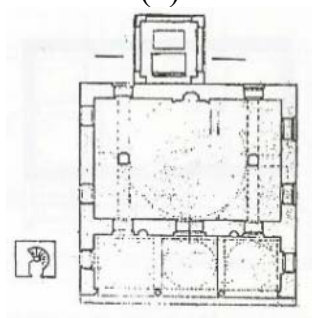

(d)

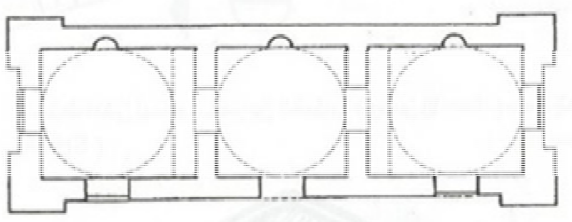

(f)

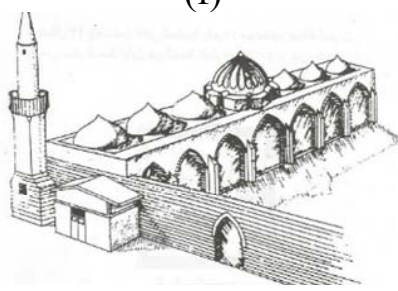

(h)

Figure 25: A horizontal plan for different tombs and Mosque similar plan Al-Fatih Masjid. (a) A horizontal plane of the tomb of Ms. Ruqaya (Source: Othman, 2006); (b) A horizontal plane of the tomb of Aswan in southern Egypt (Source: AlHaddad, 2004); (c) A horizontal plan of the Mojahdi Mosque in Mosul (Source: Al-Haddad, 2004); (d) Nebi cami plan of Diyar Bakr (Source: AlHaddad, 2004); (e) A horizontal plan of Al-Safa Mosque in Diyar Bakr (Source: Al-Haddad, 2004); (f) Horizontal port of the Mosque of Al-Suqayya Medina (Source: Moustafa, 1981); (g) Horizontal outline of Al-Jumah Mosque in Medina (Source: Shaaban, 1987); and (h) The façade of Ali ibn Abi Talib Mosque in Medina (Source: Moustafa, 1981.) 


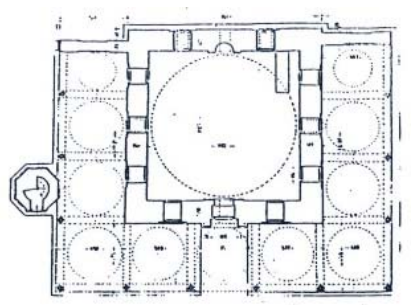

(a)

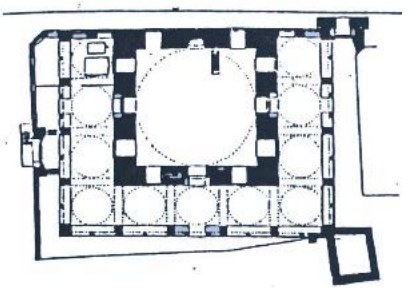

(b)

Figure 26: A horizontal plan for different tombs and Mosque similar plan Al-Qubba Jami. (a) The layout of the Larry Mosque in Edirna (Source: Yuksel, 1983); and (b) A plan of the Abu Dahab Mosque towards Al-Azhar in Cairo (Source: Al-Haddad, 2004).

The oldest remaining example of this planning is the Mosque of Haidariyya in Caspian. We note how the Ottoman style moved from the capital Istanbul to Al-Ahsa with the art which is called "absolute spatial architecture", with a total variation of the volume of spatial forms to be smaller and simpler in terms of decoration and adornment. Compared to those of huge Mosques spread in the capital of the Ottoman Empire, Istanbul, or Edirna, Suleymaniye Mosque includes other facilities, such as a library, a hospital, a bathroom, schools, and a hospice.

\subsection{Structural, architectural, and decorative elements}

There are many architectural elements that vary according to their architectural and decorative functions and forms, and the most important architectural and decorative elements are the Masjid and Jami.

\subsubsection{Façades}

\subsubsection{External façades}

The main façade of Al-Fatih Mosque is characterized by a hall of five pointed arches with a domed roof led to the front yard of a Mosque, and the northern, southern, and eastern façades of Al-Qouba Mosque.

Each of them also has a portico consisting of an arcade with five lobular tampered arches with a vaulted ceiling, compatible with a lot of Ottoman Mosques façades, as seen in Aski Mosque in Edirna (805 AH/1403 AD) and Bayazid II Mosque in Amasia (891 AH/1486 AD)

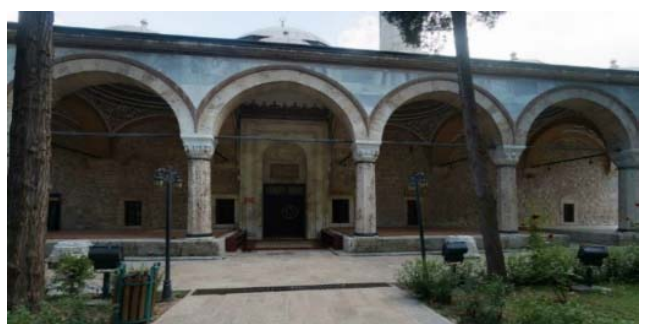

Figure 27: The exterior façade of Mohammed Pasha Mosque in Amasia. (Source: 3D Places, 2007.) 


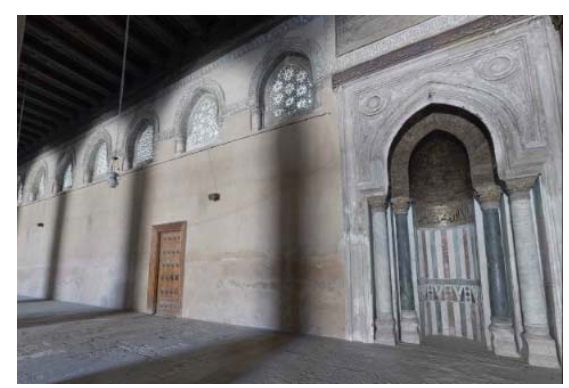

Figure 28: The inner façade of Ibn Tulun Mosque and the openings of its high windows and closer to the ceiling. (Source: 3 D Places, 2007.)

[18], and generally tends to be simple and free of exaggerated ornaments and decorations, like the rest of the buildings and Mosques of the area that are almost solid (Fig. 27).

\subsubsection{Internal façades}

They are marked as being free of colours and decorations, except for a wall of Qibla over the mihrab of Al-Qouba Jami painted with Muqarnast with white plaster, hanging from a niche, and a wall of Qibla in both Al-Jami and Al-Masjid was painted with the Qibla wall plaster over the mihrab, with plastered plaque written in the Thuluth script that specifies the date of building of Al-Masjid and Al-Jami. We find that the predominant colour of the walls of AlMasjid and Al-Jami is white as a result of the impact of religion on architecture, in which the majority of jurists mentioned that it is hateful to ornament Mosques, or whatever diverts the worshiper from his prayers as seen in the Mosque of Samarra in Iraq, and the Mosque of AlJabri in Al-Ahsa (Fig. 28).

\subsubsection{Coverages}

Al-Jami and Al-Masjid include three types of coverages

The first type is the shallow domes based on spherical triangles, which covered the roof of the entrance porticoes. An example are the entrance porches at Al-Fatih Mosque and AlQouba Jami, which have spherical diameters that are equivalent to the spherical diameters of domes they carry. In this case, the triangles seem as a part of the full body of the dome above the triangles in the form of a large bowl, or a hollow spherical bend, with a half circular section invented by the Arab Al Shame in their country since the fourth century AD. They used them to shift square areas to round areas based on the lower edges of the domes, as seen in Nuejis palace in Amman [15]. The Mosque of Al-Fateh in Al-Ahsa was pioneered to use this type of coverings in Al-Ahsa, followed by Al-Qouba Mosque, and this type is also found in the domes of the Fatimid Al-Akmar Mosque [20] and in the Ottoman period in Al-Jabri Mosque in Al-Ahsa (1092AH/1681AD) [6] (Fig. 29).

The second type is the inflatable domes with an elongation similar to the shape of the cross bunker, but the intersection angles do not appear either inside or outside. This type of domes is elongated due to the covering of rectangular spaces [19], as in the domes of AlFatih Mosque covering the three areas of the chapel and classroom space. This type of domes was seen the first time in Al-Ahsa in this Mosque. Their use has spread to India in the Mongol Era and is known as the Bengali domes, an Indian influence that moved to Al-Ahsa due to economic activity between Al-Ahsa and India, which can be seen in the Mosque of Pijamburi (728-751 AH/1325-1351 AD) [21], as we see in the Great Mosque in the House of the Faqih in Yemen (864-883 AH/1460-1478 AD) [17] (Fig. 30). 


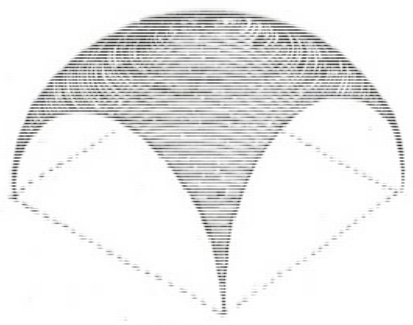

(a)

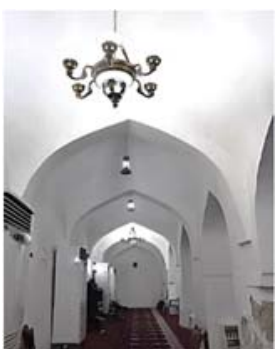

(b)

Figure 29: Shallow domes for other Mosques. (a) Three-dimensional sketch of a shallow dome (Source: Shafi'i, 1994); and (b) The shallow domes of the Al-Jabri Mosque (Source: From the work of the researcher).

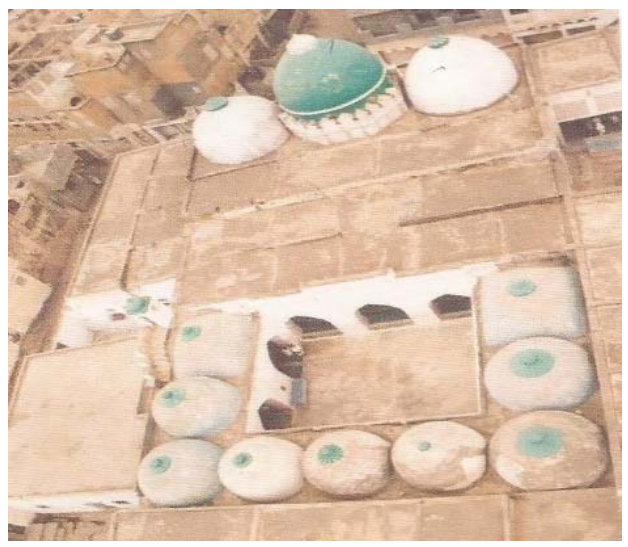

Figure 30: The roof of the Great Mosque in Beit Al-Faqih. (Source: Al-Haddad, 2014.)

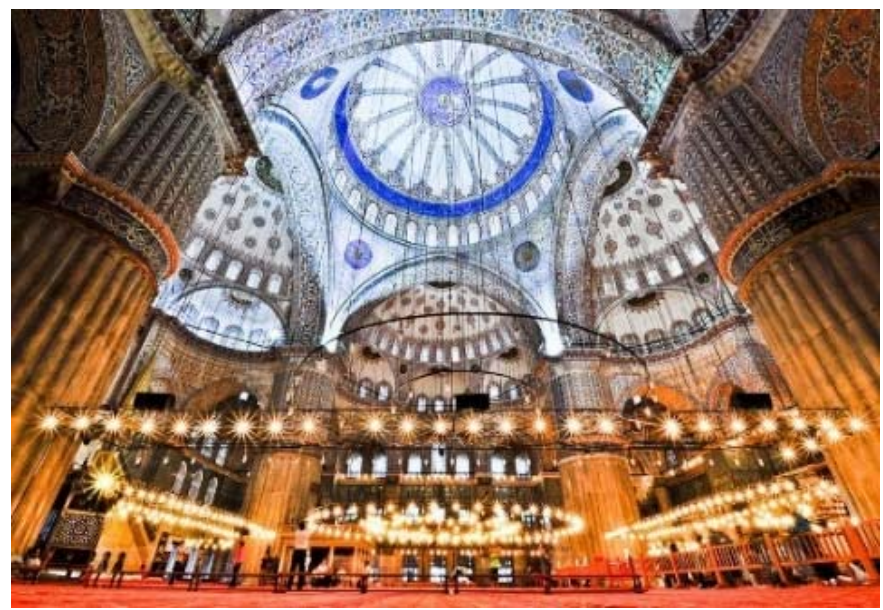

Figure 31: Dome of Sultan Ahmet Mosque in Turkey. (Source: Flicker Explore, 2012.) 
The third type is a central dome with the square-domed building being the main architectural element during the Ottoman Era. The dome completely dominated space, straining it to the centre. It was a round spherical dome, centralized on an octagonal or circular base, or knotted pinkies, or over structural components consisting of Polygonal triangles with the space between the dome circle and the straight walls at the four corners, such as the Ala'a Uddin Mosque in Bursa. In the Mosque of Al-Qubba, it is based on knotted pinkies with a tapered arch, such as the Mosque of Sultan Ahmed in Istanbul and the Mosque of Omar ibn Al-Khattab in Medina (Fig. 31).

\subsubsection{Levers}

Several types of stents and arches were used in the Mosque, and some of them were repaired, added, and removed during the stages of their restoration.

\subsubsection{Pillars}

It is a new structural element of Islamic architectural innovation and had eliminated the use of cylindrical columns; some of which were taken from ancient buildings, especially those made of marble or granite due to the difficulty of extraction, transfer, and formation. It was first used in the Dome of the Rock in the Al-Aqsa Mosque in Jerusalem (71 AH/691 AD) [15].

The Mosque and the Dome of the Rock contain two types of cylindrical pillars. All of them were entirely built of limestone and covered with plaster and luting, which are as follow: The first type is wide cylindrical pillars shown in Al-Qouba Mosque, cylindrical pillars, with a wide diameter, crowned with a square crown in traditional architecture called qana'ah [22], with an arch rest on an arcade of the entrance portico. We find such pillars in Al-Jabri Mosque (870 AH/1465 AD) and in the Abbasi Mosque, known as Masjid Tarek Khan, in Damgan, Iran, which can be dated back to the 2nd century AH/8 AD [23] (Al-Rehawi, 1990: 150) (Fig. 32).

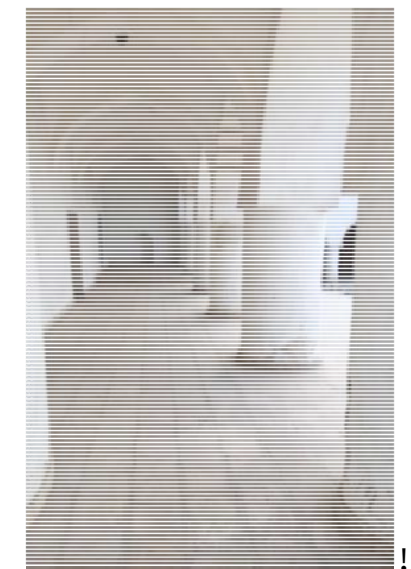

(a)

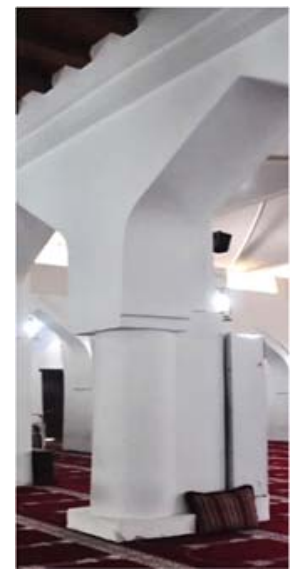

(b)

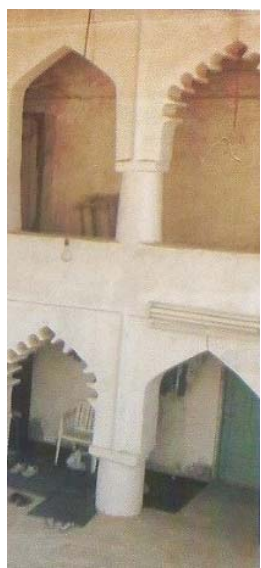

(c)

Figure 32: The pillars similar to the Qubba Jami. (a) The pillars of Jami AlQouba and in the centre of northern portico is a small hollow niche side (Source: From the work of the researcher); (b) The pillars of the Jabri Mosque (Source: From the work of the researcher); and (c) The pillars of the bond of Abu Bakr Al-Mulla (Source: Arfaj, 2011). 


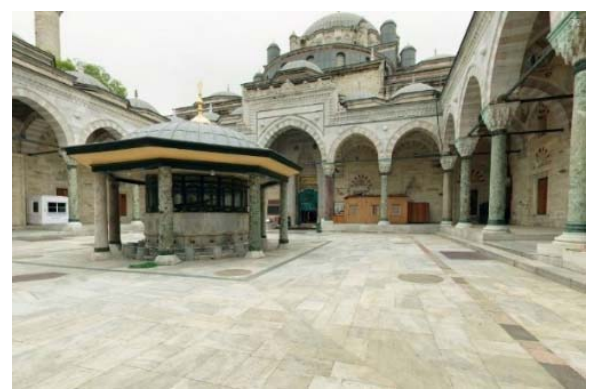

(a)

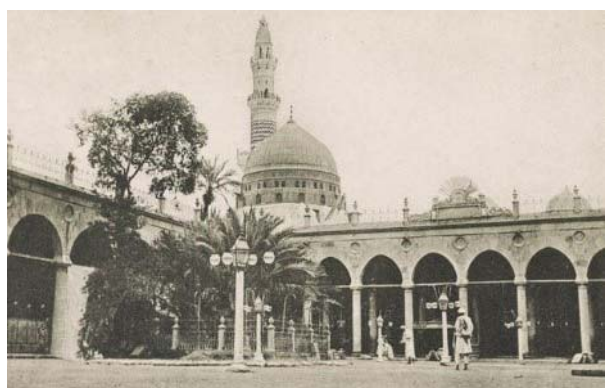

(b)!

Figure 33: The pillars similar to the pillars of Al-Fateh Mosque. (a) The pillars of the Mosque of Sultan Bayezid II appear in Amasia (Source: 3D Places, 2007); and (b) The pillars of the Prophet's Mosque in Medina (Source: Pasha, 1925).

The second type is high limber cylindrical pillars, appearing in Al-Fatih Mosque. Each one is crowned with two stones called qana'ah. The lower qana'ah is smaller than the next to receiving arches, which is one of the traditional model, as found in Siddus Mosque in Riyadh [12], the Ottoman Hall in Al-Haram Al-Makki (979-984 AH/1571-1576 AD), and the Prophet's Mosque (1265-1277 AH/1849-1861 AD) [24] (Pasha, 1925: 241,465). We find these pillars in the canopy of the entrance in the Ottoman buildings, such as the façade of the prayer hall in Bayazid II Mosque in Amasia (891 AH/1486 AD) [18] (Fig. 33).

\subsubsection{Arches}

Arches are one of the most important architectural elements used in the Mosques of Al-Ahsa. The hot environment of Al-Ahsa imposed on the building height, especially the coverings, in order to facilitate air movement inside cavity coverages, thereby cooling the air temperature inside, so the arches are the appropriate tool for covering height along with their use in the coronation of niches and various entrances. Through our descriptive study of Al-Fatih Mosque and Al-Qouba Jami, we find two types of arches:

The first type is Al-Qouba Jami with five lobar arches, consisting of 11 lobes, in the arcade of the entrance canopy, and its use was spread in Al-Ahsa. It was found in Al-Jabri Mosque in $870 \mathrm{AH} / 1465 \mathrm{AD}$ and the Great Mosque in Tlemcen in $1360 \mathrm{AH} / 1941 \mathrm{AD}$ [8]. As for the rooting of this type of arch, as found in Taq Kasra (Iwan Kasra'a) in Ctesiphon, it was found in the Islamic Era at the door of Baghdad in the city of Raqqa (155 AH/772 AD) [25] (Fig. 34).

The second type is a two focal-pointed arch, consisting of brackets drawn from two foci. The two brackets meet at the top of the pointed arch. This type of arch was found in Al-Fatih Mosque, the classroom annexed to it from the inside, and in the corner bends of Al-Qouba Jami from the inside, as well as in the arcade of the entrance portico of both Al-Fatih and AlQouba Mosques. This arch was known before Islam in the church of Qasr ibn Wardan in Homs (561-564 AD). Nine windows were found crowned in the back façade of Qasr (531579 AD) or in the year between 242 and 272 AD. Also, during the Islamic Era, it was used in the Umayyad Mosque arches in Damascus (87-707 AH/705-715 AD) [17] (Fig. 35).

\subsubsection{Entrances}

The entrances used in the Mosques varied between main entrances and secondary entrances. It is noted that all the entrances of Al-Fatih Mosque and Al-Qouba Jami are simple and direct, 


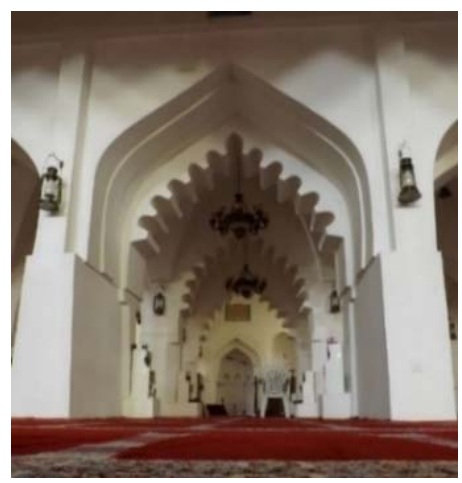

(a)

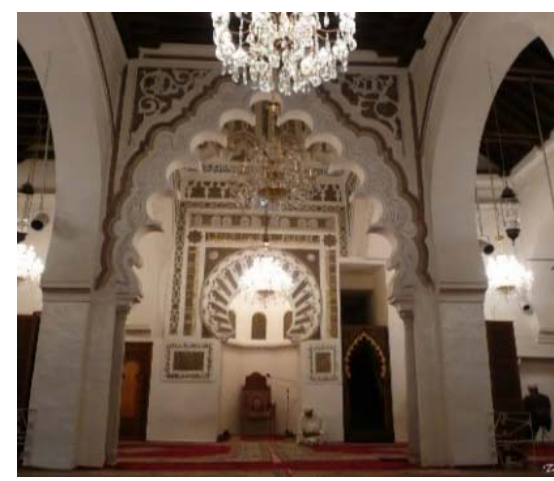

(b)

Figure 34: The Lobar Arches. (a) Lobar arches in the Al-Jabri Mosque (Source: From the work of the researcher); and (b) Lobar arches in the Great Mosque in Tlemcen, Algeria (Source: Google Panorama, 2011).

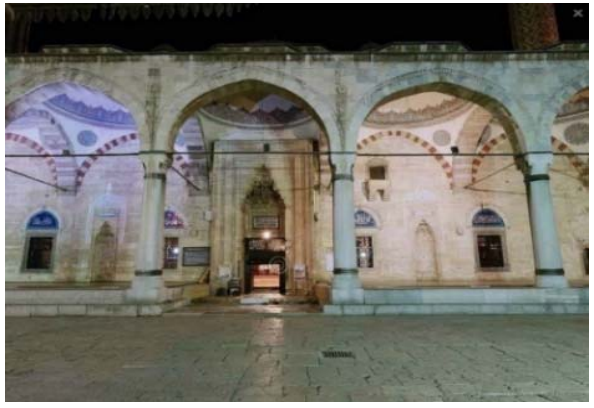

(a)

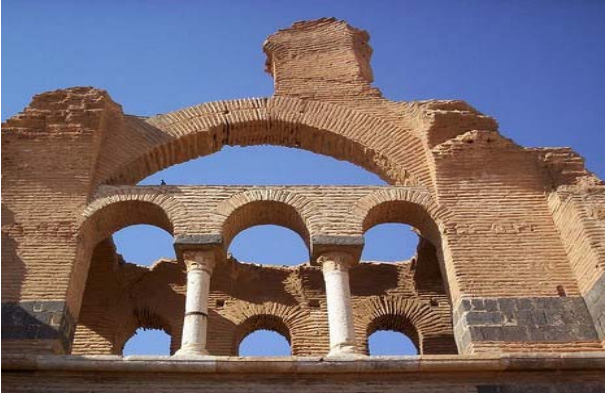

(b)

Figure 35: Pointed arches. (a) The pointed arch at Sultan Beyazid II Mosque in Istanbul (Source: 3D Places, 2007); and (b) The pointed arch at the palace of Ibn Wardan in Homs (Source: Wikipedia, 2001).

and their doors are at the level of the wall, leading directly from the street to the Mosque block, which is characterized as being free of decorative aesthetic elements.

With multiple entrances to the Mosque and Al-Jami and the different locations, they were chosen based on the function of each entrance and the population density near the Mosque. Also, they differ in the entry to the building because of the different ground level of high and low street compared to the building.

The entrances of Al-Fatih Mosque link the courtyard to the chapel in the Mosque and the lesson hall, whereas the entrances of Al-Qouba Jami link the prayer hall to the palace square, with porticoes in the front of each entrance and with domes free of decorative elements. We see such entrances in the Al-Sharafiya Mosque in Al-Hofuf and the Mosque of the Prophet Muhammad, or also known as Al-Tuba'a meaning "repentance", in Tabuk in 1325 AH/1907 $\mathrm{AD}$ [54]. We also see this type of entrances, led by the portico in the Ottoman buildings, in the Mosque of Tash in Konya (612 AH/1215 AD) [23] and the entrance of Yeni minare cami in Diyar Bakr (894 AH/1489 AD) [18]. 


\subsubsection{The mihrab}

The mihrab is one of the main architectural elements in the architecture of Mosques. It is a bend in the Qibla wall, often in the middle of the Qibla wall, hollowed with a rectangular, ribbed, or semi-circular elevation with orthogonal sides, used in the Mosques as a mark to the direction of Qibla of Makkah (Holy Kaaba).

The mihrab in Al-Fatih Mosque and Al-Qouba Jami is characterized by its bend buried in the thickness of the Qibla wall and does not stand out from the outside. This is one of the characteristics of Islamic Ottoman architecture, for example, the Al-Jumah Mosque in Medina (939-948 AH/1532-1542 AD) [11], and outside the Arabian Peninsula of the Mosque of Tash in Konya, Turkey (612 AH/1215 AD).

The mihrab of the Mosque consists of six-sided shallow bend, with a façade of a twocentred, tampered arch. We find many polygonal mihrabs in the Ottoman architecture, such as the mihrab of Yeni minare cami in Diyar Bakr (894 AH/1489 AD) and the Mosque of Sultan Beyazid II in Amasia (891 AH/1486 AD) [18] (Fig. 36).

\subsubsection{Minbar}

Minbar is an important architectural element that we cannot see, except in the collecting Mosque, located on the right of the mihrab. It is used as footstep of the Mosque's khateeb, or a speaker who delivers the sermon, for the Friday prayer, whether the minbar is made of wood or glass or inside the wall with stairs.

Minbar of Al-Qouba Jami is located on the right of the mihrab, and it stands out from the wall of the Qibla, which consists of three built stairs, ending at a wider and longer threshold. This model of minbar is found in Al-Adiliyah Mosque in Aleppo (957 AH/1550 AD), AlFatih Jami in Istanbul (868 AH/1463 AD) [14]. The minbar of Al-Qouba Jami differs from it, for it is simple and devoid of architectural and decorative elements.

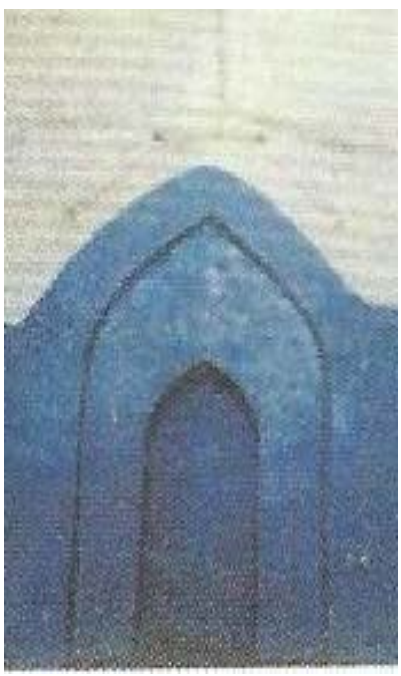

(a)

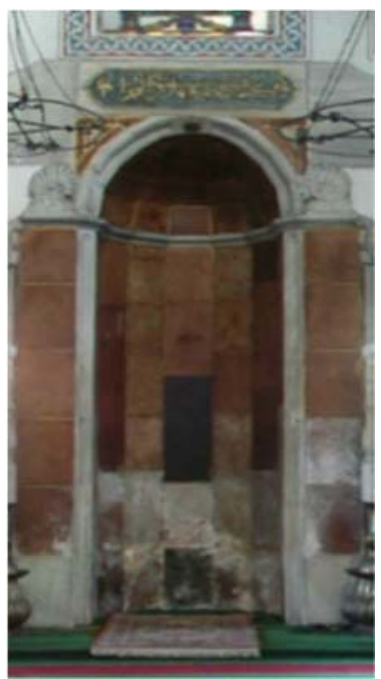

(b)

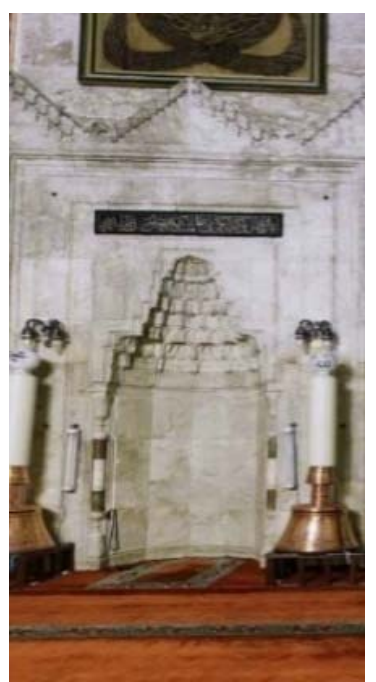

(c)

Figure 36: Similar to the mihrab of Al-Fateh Mosque and Al-Qouba Mosque. (a) Mihrab Al-Jumah Mosque in Medina (Source: Al-Haddad, 2004); (b) The Little Aye Sophia Mosque in Istanbul (Source: 3 D Places, 2007); and (c) The Mosque of Sultan Beyazid II in Amasia (Source: 3D Places, 2007). 


\subsubsection{Minarets}

The minaret was linked to the architecture of Mosques, chapels, schools, and religious facilities for the purpose of calling prayer and reporting it to the largest number of people. There were numerous minarets in the Mosques, so that they were not limited to the presence of one minaret, with square, polygonal, and cylindrical forms and various styles, considered one of the Seljuk architectural styles.

The cylindrical minarets appeared in the oasis of Al-Ahsa, especially in Al-Hofuf during the reign of the Al-Jabriyah and Ottoman Empire, despite similar minarets in the eastern Arabian Peninsula and Yemen, as a result of the exposure of these regions to the same affecting factors on its architecture from the economic, political, and environmental aspects with differences to distinguish one from another.

Throughout this period, architecture in Al-Ahsa has highlighted the minaret as an architectural unit within the block of the Mosque. Therefore, it has always been built on visible sites, especially on the main façades. The minaret may be linked to the Mosque, such as the minaret of Al-Qouba Jami, or separate from it, such as the minaret of Al-Fatih Mosque (Al-Dibs).

The minarets of Al-Fatih Mosque and Al-Qouba Jami consist of a high cylindrical tower that extends in the shape of a cone which narrows gradually as rising up to an external balcony made of wooden plaster muqarnas. The building rises again, continues with a second inapparent balcony, and opens with four arches mounted by a completed dome to the extension of the minaret, which is then topped by a pommel and a crescent, as seen in the minaret of Al-Ashrafieh Mosque in Al-Ahsa, which ends with inapparent balcony and a dome [12], and the minaret of Manar Mosque in Al-Qatif (8 AH/14 AD) [26], [27].

The cylindrical minaret with its vaulted terrace of top muqarnas of Al-Khamis Mosque in Bahrain (99 AH/717 AD) (Fig. 37). From the inside, the minaret of the Al-Fatih Mosque and the minaret of Al-Qouba Jami located in the south-eastern corner include a spiral staircase that the muezzin ascends to the upper balcony. The spiral staircase is the easiest stairway to board for the blind [28], [29].

\subsubsection{Wells}

Most of the Mosques have their own wells in Al-Ahsa because of the nature of the agricultural area, where each home or farm has a private well, as Lorimer mentioned in his book.

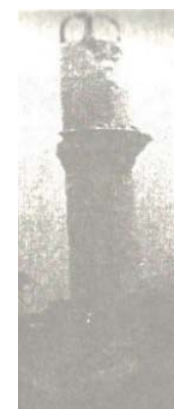

(a)

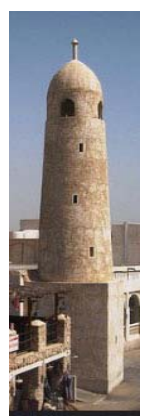

(b)

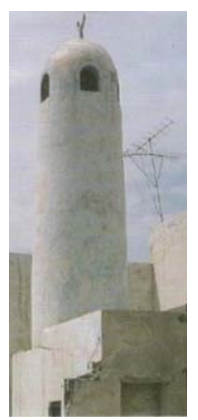

(c)

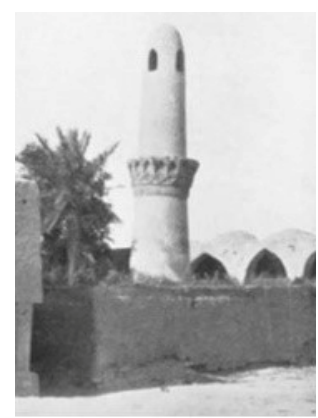

(d)

Figure 37: Similar to the minaret of the Mosque and Al-Jami. (a) Minaret of Manar Mosque in Al-Qatif (Source: Muslim, 2002); (b) Minaret of Al-Ahmad Mosque in Qatar (Source: Ramadan, 2009); (c) Minaret of the Mosque of Ashrafieh (Source: King, 1986); and (d) Minaret of the Mosque of Al-Fatih (Source: Mackie, 1924). 

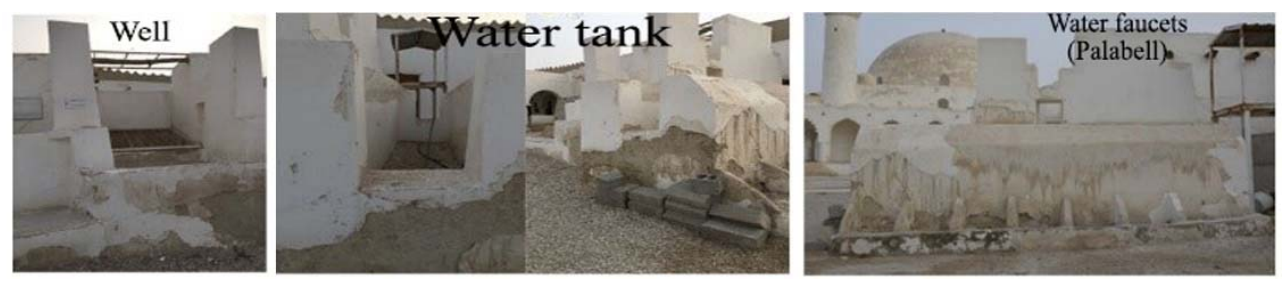

Figure 38: Ablution Al-Qouba Jami is similar to the old Mosque of Al-Fatih. (Source: From the work of the researcher.)

Both Al-Fatih Mosque and Al-Qouba Jami have wells drilled into in the ground, which are located in the front yard of Al-Fatih and the square of Ibrahim's palace near Al-Qouba Jami. The wells serve the orchard and the worshipers. Their availability in the Mosques is prevalent in the region, and we see this in Al-Jabri Jami in Al-Ahsa, in addition to the well of the Great Mosque in Beit Al-Faqih in Yemen [17].

\subsubsection{Ablution basin}

The ablution basin was a room annexed to the Mosque on the east side and an open area for ablution on the western side of the palace square. It is a well next to a basin built of plaster to prevent water leakage as a tank to collect water, containing ten holes by five on each side and comprising water taps called balabeel, and it can be opened and closed by a piece of wrapped cloth to formulate the plug between each tap and another a plaster barrier. This style in building ablution has spread in Al-Ahsa as found in the ablution of Al-bin Zaid Mosque and the Sheikh Abdul Aziz Al-Alalji Mosque (Fig. 38), [8].

\subsubsection{Windows}

They are one of the architectural elements especially designed for lighting and ventilation of the Mosque and Jami, which help the passage of air currents and natural lighting within them. Internal ventilation is linked to the percentage of openings with a façade of the building. In the hot and dry area, the hot air outside the building, during the daytime, is a source of high internal temperature, and the cold air at night causes its decline, such as the study area. This is not controlled only by increasing the movement of outside air, but it is controlled when entering into the building, taking into account the selection the appropriate positioned openings in the outer walls of the Mosque and Jami, and when determining the capacity and number.

As found in Al-Fatih Mosque and Al-Qouba Jami, arched holes open in the upper wall above the doors and under the roof of the domes. We note this in the Ottoman Mosques in Turkey. There are windows under the upper windows, such as Al-Qouba Jami, but the AlFatih Mosque is devoid of that, for example, Al-Jumah Mosque in Medina (939-948 AH/ 1532-1542 AD) [11], the Yildirim Mosque in Bursa (792-797 AH/1390-1395 AD), and the old Mosque in Edirna Aski Jami (805-816 AH/1404-1414) [18] (Fig. 10, 20).

\subsubsection{Wall gaps}

There are a variety of ways to store books, the Holy Quran, placing lamps or lighters in the Mosque, and Jami varies between placing them inside the so-called Alqowha or as follows:

A. ALQOWHA: It appears in the northern wall of Al-Fatih Mosque and next to the mihrab, which is a rectangular cavity adjacent to the mihrab. It was made at the time of 


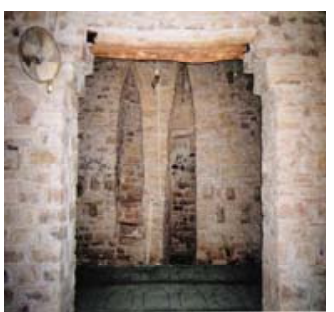

(a)

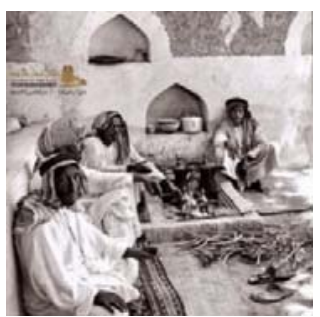

(b)

Figure 39: Wall gaps is called "Al-Qowha." (a) The gap in the walls of Douma Al-Jandal Mosque (Source: King, 1986); and (b) The gap in the wall of a sitting area for drinking coffee in Ahsa 1928 (Source: Ramadan, 2012).

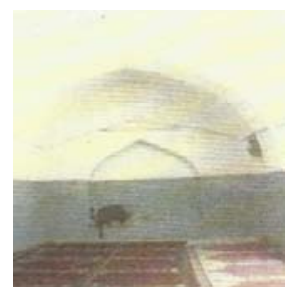

(a)

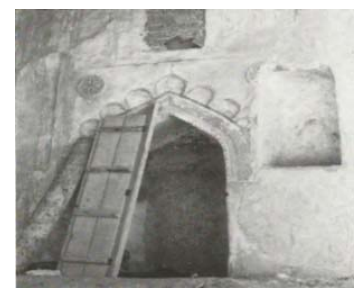

(b)

Figure 40: Wall gaps is called "Al-Faregha." (a) The gap in the walls of Al-Jumah Mosque (Source: Al-Haddad, 2004); and (b) The gap in the wall of Al-Qara Mosque in Al-Ahsa (Source: King, 1986).

the construction of the wall before claying, and it is called "before Meshashah" (Meshashah: Meshash of walls or what is known claying the walls, which is the last stage in the construction process to accomplish construction work, in cladding the walls of the building from the inside and outside and are performed manually), similar to that of the Ruzneh in terms of function, location, and decorative elements. However, the clove is larger [30], similar to the Mosque of Omar ibn Al-Khattab in Doumaa Al-Jandal, [69], and the Book of Al-Qouba Jami in Ibrahim's and Othman school in Al-Ahsa [8] (Fig. 39).

B. AL-FAREGHA: It is located in the northern wall of Al-Fatih Mosque, as seen in the northern wall of the classroom, and the southern wall of the front yard opposite the entrance of the classroom. Al-Faregha consists of a large space in the walls of Al-Fatih Mosque, in the form of the closed window (Fig. 40), which functions as the clove. However, Al-Faregha, in terms of style, is not provided with cosmetic plaster elements [30]. We find it in the Mosque of Qara in Al-Ahsa, the Mosque of Al-Aqeer [12], Al-Qouba School [8], and AlJumah Mosque in Medina [11].

\section{REFERENCES}

[1] Al-Jasser, H., The Geographical Lexicon of the Arab States of Arabia - Eastern Region (Old Bahrain), Part. 4, 1st ed., Dar Al Yamamah: Riyadh, p. 1850, p. 1521, 1979.

[2] Al Mulla, A.O., History of Hajer, Part. 2, 2nd Edition, Al Jawad Press: Al-Ahsa, pp. 220-223, 1991. 
[3] Al-Wahbi, A.K.A.A-M., The Ottomans and the Eastern Peninsula of the Arabian Peninsula "Ila Al-Hasa" 954-1082 H/1547-1671M, 1st ed., Al-Humaidhi Printing Press: Riyadh, p. 267, 2004.

[4] Lorimer, G., The Gulf Guide: Historical and Geographical Section II, Emiri Library: Qatar, p. 936, D.T.

[5] Farid, M., The History of The Ottomans, To Achieve: Ihsan Hakki, 1st ed., Dar Nafaes: Beirut, p. 198, 1981.

[6] Al-Mudarra, A., Aljabri and Alfatih Masjed at Alkut neighborhood in the city of Alhofuf during the centuries 9-10AH/15th-16th, Master thesis, King Saud University, p. 378 , pp. 375-376, pp. 374, p. 384, p. 371, p. 447, 2017.

[7] Statement from the Director of the branch of the General Authority for Tourism and National Heritage Mr. Waleed Al-Hussein and the formative artist Mr. Abdulrahman Al-Sulaiman.

[8] Al-Arfaj, Anwar Mohammed, Islamic schools and Mosques in Al-Ahsa, 1st ed., AlAhsa, p. 128, p. 150. pp. 140-150, pp. 20-25, 2011.

[9] Ghobashi, A.M., Study of some Ottoman buildings in Hofuf in the second half of the tenth century AH. Master thesis, Unpublished, Umm Al-Qura University, College of Sharia and Islamic Studies: Makkah, pp. 128-130, p. 48, pp. 128-130, 1986.

[10] King, G.R.D, The Historical Mosques of Saudi Arabia, Graficas Estella, S.A: Spain, pp. 190, 1986.

[11] Haddad, M.H.I., The Dome of the Mosque in Medina and Hofuf. Series of Islamic Architecture in the Arabian Peninsula, 2nd ed., Zahraa Al Sharq Library: Cairo, p. 33, p. 30, p. 34, pp. 22-28, p. 26, p. 28, p. 32, p. 152, p. 26, pp. 26-33, 2004.

[12] Vidal, F.H., Al-Ahsa Oasis, Translated by: Abdullah Al-Subaie, King Saud University: Riyadh, pp. 104-112, 1990.

[13] Zine El Abidine, M., Ottoman Mosque Building, 1st ed., Dar Gabes: Beirut, p. 118, p. 52, p. 112, p. 42, p. 98, 2006.

[14] Shafi'i, F., Islamic Architecture in Islamic Egypt, Era of the Governors, 1st ed., Egyptian General Book Authority: Cairo, p. 239, p. 139, p. 403, p. 174, 1994.

[15] Okasha, T., Islamic aesthetic values, 1st ed., Dar Al Ma'arif: Cairo, p. 20, 1994.

[16] Al-Haddad, A.A.S., The Great Mosque in the House of the Faqih in Yemen, pp. 7-10, pp. 13-16, King Saud University Journal, College of Tourism and Antiquities, 26(2), Riyadh, p. 30, p. 185, p. 189, 2014.

[17] Aslan Abba, O., The Arts of the Turks and Their Emergencies, Translated by: Ahmed Mohamed Issa, 1st ed., Research Center for Islamic History, Art and Culture: Istanbul, pp. 148-149, pp. 189-204, pp. 163-199, pp. 163-189, p. 148, p. 189, p. 175, p. 180, 1987.

[18] Othman, M.A.-S., Encyclopedia of Fatimid Architecture - Fatimid Architecture Civilization - Civil - Religious II, 1st ed., Cairo House: Cairo, p. 346, 2006.

[19] Ali, A.R.M., History and Architecture of Ancient Mosques in India, 1st ed., Egyptian Lebanese House: Cairo, p. 245, 1997.

[20] Al-Halibah, S.Z M., Delhi City Mosques "Dahli" in India from the 6th century AH/12 $A D$ to the eleventh century $A H / 17 A D, 1$ st ed., the Arab House of Encyclopedias: Beirut, p.405, 2010.

[21] Al-Omair, A.I., Traditional Architecture in Najd, King Saud University: Riyadh, p. 33, 2007.

[22] Al-Rehawi, A.Q., Architecture in Islamic Civilization, 1st ed., King Abdulaziz University: Jeddah, p. 150, p. 207, 1990. 
[23] King, G.R.D., The Historical Mosques of Saudi Arabia, Graficas Estella, S.A: Spain, p. 146, p. 48, p. 170, p. 175, p. 170, p. 175, p. 120, pp. 179, 1986.

[24] Pasha, I.R., Mirror of the Two Holy Mosques II, 1st ed., Egyptian Book House: Cairo, p. 241, p. 465, 1925.

[25] Al-Haddad, A.A.S., Introduction to Islamic Antiquities, 1st ed., Dar Al-Shawkani: Sana'a, p. 128, 2003.

[26] Al Musallam, A., The Dwelling Traditional in Al-Hasa, Analytical Study of Al-kut District of Al-Hofuf, (Unpublished MA dissertation), Urban and Regional Planning Department, College of Architecture and Planning, King Fasiel University: Dammam, p. 79, 1996.

[27] Mackie, J.B., Hasa: An Arabian Oasis. The Geographical Journal, 63(3), pp. 189207, 1924.

[28] Hassan, N.M., Creative Profiles of Islamic Architecture, 1st ed., King Saud University: Riyadh, p. 76, 2010.

[29] Alp, A., The Architectural Heritage of Saudi Arabia Eastern Province, College of Environmental Design, (Unpublished MA dissertation), King Fahad University of Petroleum \& Minerals: Dhahran, p. 293, 1990.

[30] Al-Omair, A.I., Traditional Architecture in Najd, King Saud University: Riyadh, pp. 155-154, 2007. 